\title{
Toxicity associated with the photo catalytic and photo stable forms of titanium dioxide nanoparticles used in sunscreen
}

\begin{abstract}
The increasing number of applications using titanium dioxide nanoparticles (nano- $\mathrm{TiO}_{2}$ ) highlights the need to continuously and systematically investigate its toxicity. Particle size, surface area and dose are the classical parameters considered when performing toxicity studies. However, consideration of the size-related properties and altered reactivity can unveil complex and unexpected phenomena arising from the interplay of the different factors. In addition to particle size, altered reactivity can be induced by intentional or unintentional modifications of the nanoparticles by their surrounding matrix. This effect could potentially influence the nanoparticles' band gap, surface reactivity, agglomeration, mobility and photo catalytic behavior. The remarkable ability to absorb impurities from the surrounding medium could transform nano- $\mathrm{TiO}_{2}$ into a surrogate carrier of trace elements (e.g., heavy metal ions), which heightens their transportation and intracellular accumulation. This review outlines the different characteristics and interactions that may contribute to the underlying mechanisms of health and environmental toxicity of nano- $\mathrm{TiO}_{2}$, and identifies gaps in current understanding.
\end{abstract}

Keywords: nanomaterials, nanotoxicology, nano-tio ${ }_{2}$ toxicity, titanium dioxide toxicity, sunscreens, cosmetics
Volume I Issue 3 - 2015

\author{
Shazia Tanvir, Sylviane Pulvin, William A \\ Anderson \\ Department of Chemical Engineering, University of Waterloo, \\ Canada
}

Correspondence: Sylviane Pulvin, Department of Chemical Engineering, University of Waterloo 200 University Avenue West, Waterloo, ON N2L 3GI, Canada, Tel 5198884567, Emails2tanvir@uwaterloo.ca

Received: April 15, 20I4 | Published: June 12, 2015
Abbreviations: IARC, international agency for research on cancer; UV, ultraviolet; QD, quantum dot; ROS, reactive oxygen species; PBS, phosphate buffered saline; $\mathrm{CB}$, conduction band

\section{Introduction}

The properties of materials change as their size approaches the nano particle scale, which is generally considered to be that with at least one dimension of $100 \mathrm{~nm}$ or less. The toxicity of nanoparticles has been linked to such characteristics as elemental composition, charge, shape, Crystallinity, surface area, solubility and surface chemistry/ derivatization. ${ }^{1-6}$ Understanding the nano particle-cell interaction is thought to be critical for the safe development of nano materials. It seems unlikely that the potential toxicity of nanoparticles and the underlying mechanisms can be predicted or explained by any single unifying concept.

This review is focused on Titania $\left(\mathrm{TiO}_{2}\right)$ for which there is substantial interest in the chemical, biological, and industrial worlds because of its fascinating and useful physicochemical properties. Currently, information describing the relative health and environmental risks associated with nano- $\mathrm{TiO}_{2}$ is severely lacking. Only recently, critical questions regarding the potential human health and environmental impact of nano- $\mathrm{TiO}_{2}$ have been raised.$^{8-11} \mathrm{TiO}_{2}$ particles have long been considered to pose little risk to respiratory health because they are both chemically and thermally stable. ${ }^{12}$ However, $\mathrm{TiO}_{2}$ is classified as a Group 2B carcinogen by the International Agency for Research on Cancer (IARC) based on the findings of lung tumor induction in female rats. ${ }^{13,14}$

Nano- $\mathrm{TiO}_{2}$ is attractive for use in a large number of applications based on its unique optical and photo catalytic properties, tunable band gap, thermal stability, chemical resistance and hardness.15
Because of the relatively large band-gap, the particles absorb the higher-energy (shorter wavelength) ultraviolet radiation making it a useful constituent in sunscreen products. $\mathrm{TiO}_{2}$ photo catalysis is widely used in the fields of wastewater treatment, ${ }^{16}$ sterilization, ${ }^{17}$ self-cleaning, ${ }^{18}$ hydrogen evolution, ${ }^{19}$ and photoelectron chemical conversion. ${ }^{20}$ Normally, $\mathrm{TiO}_{2}$ can only be excited with ultraviolet (UV) light because of its wide band gap,$^{21}$ although this is considered a drawback when photo catalytic conversion is desired under visible light. The crystalline structure is the major factor determining the band gap, but secondary factors include the particle size and the presence of defects (physical or chemical). ${ }^{22,23}$ A large surface-tomass ratio of the nanoparticles helps to promote catalytic reactions, and increases their ability to absorb and carry other compounds. Their surface reactivity originates from quantum phenomena that can make nano- $\mathrm{TiO}_{2}$ seemingly unpredictable. ${ }^{24}$

Engineered nano- $\mathrm{TiO}_{2}$ is designed to impart specific characteristics that vary according to their use. Aside from unique nanoscale properties (size, Crystallinity, reactivity, and thermodynamics), nano$\mathrm{TiO}_{2}$ may be functionalized, ${ }^{25}$ doped $^{26}$ and coated to control photo catalytic activity. The differences between the applications of nano$\mathrm{TiO}_{2}$ in water remediation technologies versus consumer products are important, but the currently available information does not allow the suited differentiation. The purpose of this review is to highlight the informational gaps and to describe the physical and chemical features that may be important when performing nano toxicological studies on nano- $\mathrm{TiO}_{2}$.

\section{Nano- $\mathrm{TiO}_{2}$ in remediation technologies versus sunscreen}

Photo catalytic nano- $\mathrm{TiO}_{2}$ is in demand for remediation, sterilization and sanitation, whereas photos table nano- $\mathrm{TiO}_{2}$ is 
recommended for sunscreen use. A way to enhance or attenuate nano$\mathrm{TiO}_{2}$ photo activity is to manipulate the surface chemistry. Anatase is a particularly photoactive form of $\mathrm{TiO}_{2}$ and is used for photo oxidation reactions. ${ }^{27}$ The development of photo catalysts exhibiting high reactivity under visible light allows for a greater fraction of the solar spectrum to be used, which would be an advantage in both water and air treatment technologies. The visible light-activated $\mathrm{TiO}_{2}$ can be prepared by dye sensitization, ${ }^{28}$ external surface modifications, ${ }^{29,30}$ or band gap tailoring by doping. ${ }^{26,31}$

Nano- $\mathrm{TiO}_{2}$ acts as a sunscreen in two ways, namely absorption and scattering, which are dependent on the light wavelength. In the past, sunscreens containing metal-oxide particles appeared as opaque, white topical creams that were considered to be "unattractive". However, more transparent preparations are now available from a number of manufacturers, which has led to the use of nanoparticles in cosmetic formulations. Metal oxide particles used in such formulations span a wide range of sizes, shapes, and surface coatings. Because of the high reactivity of anatase, the rutile form of $\mathrm{TiO}_{2}$ is preferred for sunscreen use to minimize the photo catalytic effects, ${ }^{32}$ although some sunscreens still contain photo reactive nano- $\mathrm{TiO}_{2} \cdot \mathrm{TiO}_{2}$ particles are typically formulated in skin lotions as oil/water emulsions. Concerns have been raised about the product labeling issues ${ }^{33}$ and the role of the regulatory authorities in the process of identifying environmental health and safety risks related to nano- $\mathrm{TiO}_{2}$ modifications. ${ }^{11,34}$ Manufacturing technologies can produce nanometer-sized particles, but once they are formulated into a lotion agglomeration and aggregation may occur. Coatings and surfactants are used to aid in the dispersal of metal oxides; however, measuring particle size in the formulation is difficult using standard methods. ${ }^{35}$ This is particularly true after application to the skin, where surface $\mathrm{pH}$, salts, and oil may affect the coatings' dispersion and size. These issues are rarely addressed in the literature.

\section{From conventional to nano}

The term "conventional" is used to make an explicit distinction between the nanoscale material and other forms of $\mathrm{TiO}_{2}$ not having the special characteristics of nano- $\mathrm{TiO}_{2}$. Nanoparticles have a high surface are a per unit mass resulting in a high excess free energy per unit mass. This may partially explain why unique properties can be observed at the nanoscale level that are not present in the same coarse material, such as the size-dependent fluorescence emission frequency of semiconductor quantum dot (QD) nano materials. These are characterized by a high excess of energy at their surface and are thermodynamically unstable. ., $^{3,36-38}$ Crystallographic changes, such as lattice contraction or deformation, the appearance of defects, or rearrangements of the surface atoms or changes in morphology may occur to stabilize the nanoparticles. These unique nanoscale features affect the interfacial reactivity and the intrinsic properties of the nanoparticles. Research programs need to focus on sizerelated properties rather than on size alone to evaluate the safety of engineered inorganic nanoparticles. Ignoring the differences between small and truly "nano" particles may lead to inadequate interpretations of experimental results. ${ }^{38}$

\section{Physicochemical properties of Nano-TiO2}

The physicochemical properties of nano materials that have been identified as important factors in uptake and toxicity include crystal structure, size, surface charge, surface energy, and chemical composition. For human health and environmental risk evaluation, consideration of multiple aspects is required.

\section{Crystal structure}

$\mathrm{TiO}_{2}$ has three main crystalline structures: anatase (tetragonal), brookite (orthorhombic), and rutile (tetragonal). Different structures lead to different physical properties, which leads to their usage in a variety of applications. For example, anatase is employed for photo catalysis because of its high photo reactivity, while rutile's good light scattering makes it useful for pigments. ${ }^{39}$ Because anatase is more photoactive than rutile, free radical formation potential is likely higher for anatase. Regardless of the crystal form, nano- $\mathrm{TiO}_{2}$ is used in commercial sunscreen formulation. Furthermore, an anataserutile mixture is more effective than each phase separately in photo catalysis, which is dependent on the electron-hole recombination rate, crystallinity, adsorptive affinity and particle interconnection. ${ }^{40}$

Early nano toxicity studies have yielded conflicting data identifying either the size or the crystal structure as the mediating property for nano- $\mathrm{TiO}_{2}$ toxicity. ${ }^{41-43}$ Some recent studies ${ }^{44-47}$ emphasize the contribution of the crystalline structure of nano- $\mathrm{TiO}_{2}$ to the toxicity. In these studies, anatase $\mathrm{TiO}_{2}$ was found to be more potent than the rutile form of the material. Jiang et al. ${ }^{46}$ used a cell-free assay to determine the ability of nanoparticles to generate reactive oxygen species (ROS), finding a significant dependence between particle size and capacity to generate ROS. There was a clear transition in behaviour with anatase nanoparticles between $\sim 10$ and $40 \mathrm{~nm}$, with the smallest particles demonstrating a reduced capacity to generate ROS. Since it is known that the surface structure of materials can change at very small sizes, ${ }^{48}$ it is still uncertain whether this transition was size or surface chemistry mediated. The findings might be related to the density of defects on the surface of the particles, which could be another physicochemical parameter of interest in understanding the toxicity of nano materials, as suggested by the authors.

\section{Size}

The size of the particles is generally used to define materials as "nano-sized." This definition appears straight forward; however it is subject to several difficulties. First, discrepancies can arise due to the different methods and calculations used to measure particle size. Size measurements are usually based on a distribution of nanoparticles and the estimated size can be averaged by volume, weight, or area. The measurement devices use a specific environment, such as in hydrodynamic or aerodynamic sizing, and they require pre-treatment methods before measurement that can lead to discrepancies with the actual size of the nanoparticles (as determined by imaging techniques) in some circumstances.

The size, surface charge and morphology of nanoparticles exert a significant influence on the physical and chemical properties that influence their interactions with biological systems. For example, the hydrodynamic size and surface charge of nano particle dispersions can have an effect on the way in which an organism responds to exposure. The above issues have not been properly characterized in the past. This influence includes absorption, distribution, metabolism, and excretion. ${ }^{49-51}$ The size dependency of $\mathrm{TiO}_{2}$ toxicity has been demonstrated, ${ }^{41,52-55}$ appears to be applicable to a variety of $\mathrm{TiO}_{2}$ forms, and occurs regardless of the experimental settings. However, the results are based on a limited number of studies that focused on $\mathrm{TiO}_{2}$ and carbon black particles, and have fostered the perception that all nanoparticles are likely to be more toxic than larger-sized particulates. ${ }^{42,56}$ However, additional factors such as differences in the $\mathrm{TiO}_{2}$ form, particle aggregation/disaggregation potential, surface 
coatings and/or surface charge and the method of particle synthesis (i.e. whether the particle was generated in the gas or liquid phase) may be important variables influencing toxicity. ${ }^{57,58}$ Furthermore, a high degree of particle aggregation is associated with $\mathrm{TiO}_{2}$ administration such that exposure to mono disperse particles is unlikely to occur. ${ }^{59}$

\section{Agglomeration}

The terms "agglomeration" and "aggregation" are often used interchangeably in the field of nano toxicology. However, some authors have suggested that nano particle aggregation and agglomeration are distinct phenomena, whereby agglomerates are formed by clusters of particles that are held together by electrostatic interactions, while aggregates are formed by covalently fused or sintered particles that are not easily separated. ${ }^{60} \mathrm{TiO}_{2}$ nanoparticles have a large specific surface area but can easily form agglomerates in suspension depending on the strength of the particle-particle and particle-media interactions. ${ }^{61}$ Important parameters governing the state and stability of nano particle dispersions in water (Figure 1) include solution ionic strength, $\mathrm{pH}$, surface charge (zeta potential), and surface coating (hydrophobic/ hydrophilic). The degree of agglomeration is determined by the magnitude of the zeta potential in aqueous media. When nanoparticles are dispersed in an aqueous medium, surface ionization and the adsorption of cations or anions results in the generation of surface charge, resulting in the development of an electric potential between the particle surface and the medium. When the zeta potential is close to zero (isoelectric point), particles tend to agglomerate, butat highly negative (high $\mathrm{pH}$ ) or positive (low $\mathrm{pH}$ ) zeta potentials, particles in dispersions tend to repel each other such that no agglomeration occurs.

Important factors that affect zeta potential include $\mathrm{pH}$, ionic strength, and additive concentration. Ionic strength influences the nano particle's dispersion stability by changing the electrical double-layer around the particle. The electrostatic double-layer (Figure 1) (Figure 2) decreases with increasing ionic strength and consequently, weak repulsive forces result in agglomeration with large hydrodynamic diameters. At any given $\mathrm{pH}$, an increase in ionic strength generally results in increased agglomeration (Figure 2). An increase of the ionic strength diminishes the magnitude of the electrostatic repulsion, thereby resulting in an intensification of the agglomeration phenomena. Particle agglomeration is minimized by increasing surface charge, due to enhanced electrostatic repulsions between nanoparticles. The surface charge is controlled by several mechanisms, including surface ionization, ion adsorption, and lattice ion dissolution. Generally, particles have a positive surface charge at a low $\mathrm{pH}$ and a negative surface charge at a high $\mathrm{pH}$.

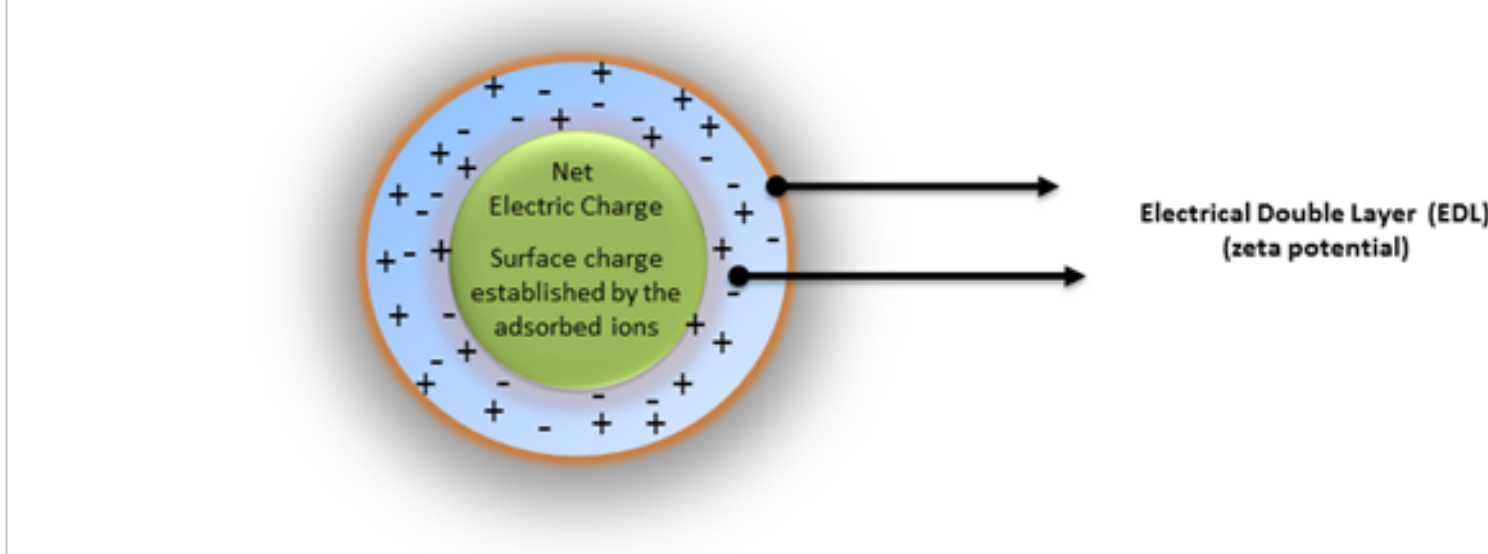

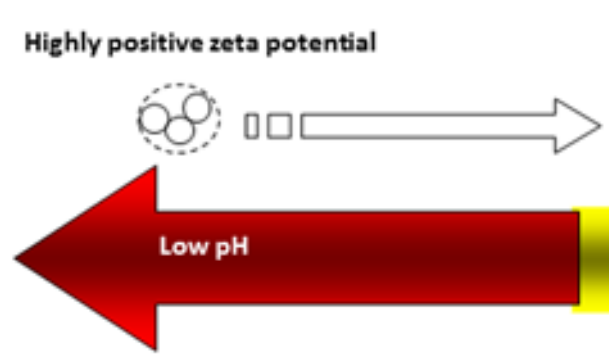

Positively charged surface

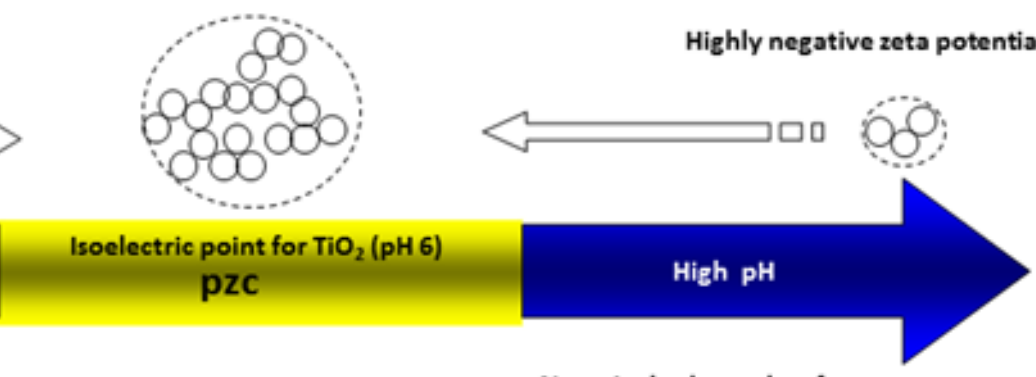

Net zero charge
Negatively charged surface

Figure I Effect of zeta potential and $\mathrm{pH}$ on the degree of agglomeration of nano- $\mathrm{TiO}_{2}$ in an aqueous solution. The pH value at point of zero charge is referred to as "pzc".

Toxicity studies have demonstrated that the hydrodynamic diameters of nano- $\mathrm{TiO}_{2}$ are significantly greater in phosphate buffered saline (PBS) than in water and that their observed sizes are often significantly larger compared to the quoted particle size. The agglomerate size is generally more than $100 \mathrm{~nm}$ and is occasionally even more than $1 \mu \mathrm{m} .^{7}$ It has been observed that both adsorbing multiply-charged ions (e.g. pyrophosphate ions) onto the $\mathrm{TiO}_{2}$ nano particle surface and coating nano crystals with polymers (e.g. polyethylene glycol) suppressed agglomeration and stabilized the dispersions. However the breakage of agglomerates into singles might not happen during real exposure scenarios. ${ }^{53}$ The behavior of nanoparticles is dependent on their solubility, susceptibility to degradation, and the fact that neither the chemical composition nor the effective particle size of the nano particle will necessarily remain constant over time. This makes it difficult to study and understand the biological Cytotoxicity of any nano particle. 

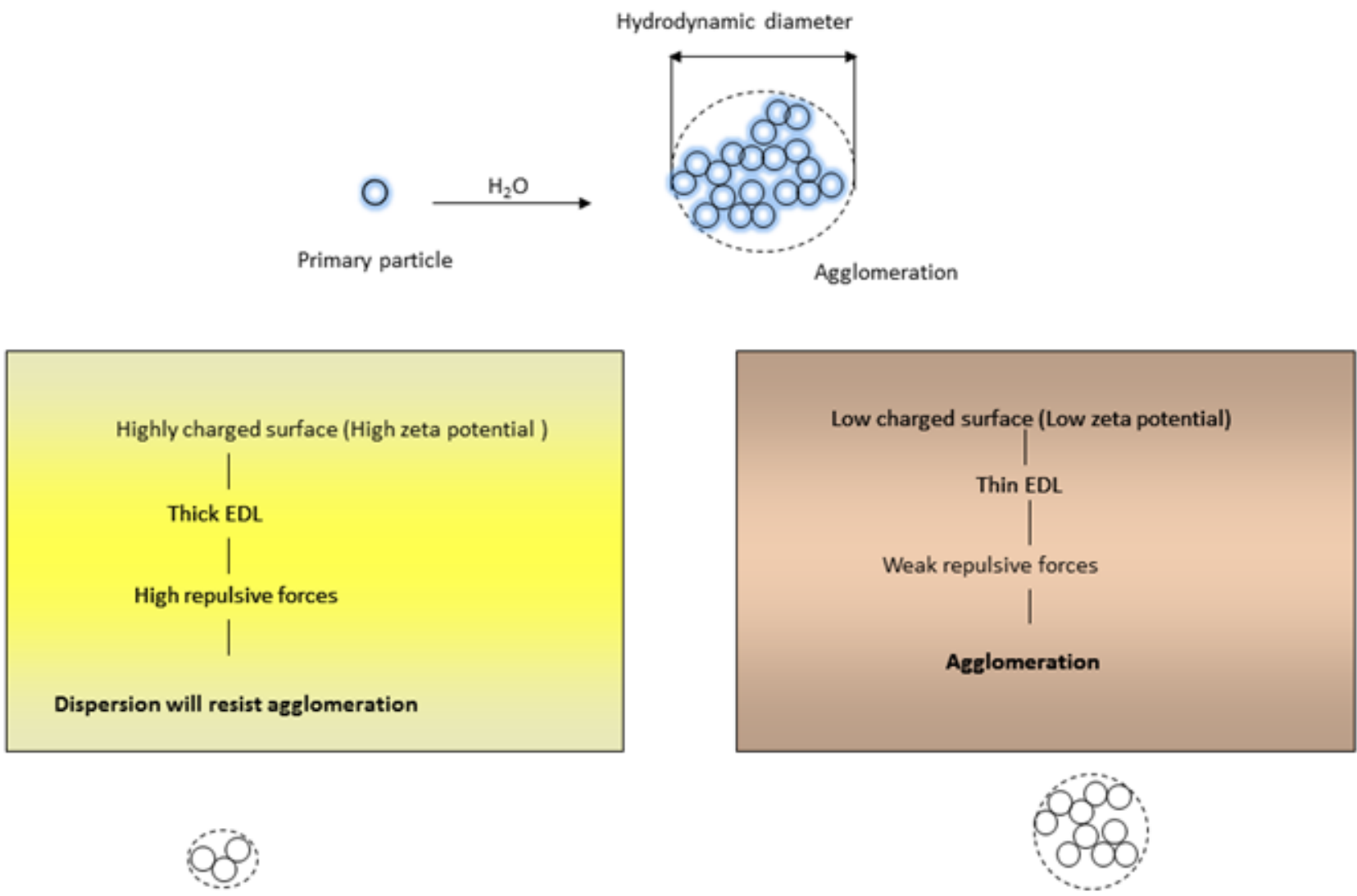

Increase in lonic strength of the solution leads to increase in hydrodynamic diameter

Figure 2 Generalized relationship between the ionic strength and zeta potential with the hydrodynamic diameters ofTiO nanoparticles in an aqueous medium.

\section{Surface chemistry}

Surface chemistry is used to tailor engineered nano particle properties according to their utility. A prerequisite for many applications is the addition of the proper surface coating and functionalization of the nanoparticles to control their environmental interactions. Coatings for nano- $\mathrm{TiO}_{2}$ particles are generally designed to reduce agglomeration/aggregation, target specific cells, modify photo catalytic properties, or improve cosmetic formulations. The coating of nano- $\mathrm{TiO}_{2}$ with polymers (e.g., polyethylene glycol) suppresses agglomeration and stabilizes the dispersion. However, a number of recent studies demonstrated that whatever the size of the nanostructures, they do not freely enter all biological systems. Their behaviour is governed by the functional molecules added to their surface. ${ }^{62}$ In an aqueous environment, low-surface-energy coatings (hydrophobic) are particularly prone to nonspecific adsorption, such

as when proteins denature to expose their hydrophobic core. Hydrophilic coatings (i.e. high surface energy), especially those resulting in a weakly negative or neutral surface charge, are ideal for resisting protein adsorption and cell uptake. ${ }^{63,64}$ The positively charged surfaces have been shown to engage in strong ionic interactions with the negatively charged cell membrane, which facilitates particle uptake into the phagosomes. Toxicity of $\mathrm{TiO}_{2}$ may be influenced by surface chemistry, but this property is likely to be dependent on the combination of surface modification and cell type.

\section{Adsorption of ions}

Most nano particle atoms are on the surface of the particle itself. The surface atoms are unsaturated, can easily bind or interact with other atoms, and possess a high chemical activity. The $\mathrm{pH}$ value plays an important role in the adsorption of different ions on oxide surfaces (Figure 3). Solution $\mathrm{pH}$ influences the surface active site distribution on metal oxides such as $\mathrm{TiO}_{2}$, and the surface hydroxyl group provides the ability to bind metal ions. ${ }^{65}$ It is well known that the surface of $\mathrm{TiO}_{2}$ is readily hydroxylated in aqueous solution. When $\mathrm{H}_{2} \mathrm{O}$ dissociates on a pure $\mathrm{TiO}_{2}$ surface, two distinctive hydroxyl groups are formed. ${ }^{66}$ The amphoteric surface will be formed because of the acid-base equilibria as shown in equation (1) and (2). Therefore, there are three kinds of surface species, $\mathrm{TiOH}_{2}+, \mathrm{TiOH}^{-}$and $\mathrm{TiO}^{-}$, and their proportion depends on the solution $\mathrm{pH}$ and the $\mathrm{pzc}(\mathrm{pH}$ at point of zero charge) of $\mathrm{TiO}_{2}{ }^{67-69}$

$$
\begin{aligned}
& \mathrm{TiOH}_{2}^{+} \rightleftharpoons \mathrm{TiOH}+\mathrm{H}^{+} . \\
& \mathrm{TiOH} \rightleftharpoons \mathrm{TiO}^{-}+\mathrm{H}^{+} . . . .
\end{aligned}
$$


At a low $\mathrm{pH}$ (below the isoelectric point), both $\mathrm{As}(\mathrm{V})$ and $\mathrm{Cr}(\mathrm{VI})$ take the anionic form, ${ }^{70-72}$ however the $\mathrm{TiO}_{2}$ surface is positively charged, which increases the extent of anionic adsorption on $\mathrm{TiO}_{2}$ The nanoparticles at a $\mathrm{pH}$ above the isoelectric point adsorb cations (Figure 3) (e.g. $\mathrm{Mn}(\mathrm{II}), \mathrm{As}(\mathrm{III}), \mathrm{As}(\mathrm{V}), \mathrm{Fe}(\mathrm{III}), \mathrm{Cu}(\mathrm{II}), \mathrm{Cd}(\mathrm{II}), \mathrm{Ni}(\mathrm{II})$, $\mathrm{Zn}(\mathrm{II}), \mathrm{Pb}(\mathrm{II}), \mathrm{Cr}(\mathrm{VI}), \mathrm{Hg}(\mathrm{II})){ }^{73-79}$ However, adsorption of ions on the $\mathrm{TiO}_{2}$ surface is not limited to the mentioned examples. These examples were noted because of their possible presence in the effluent discharged from industrial sources. Even at low-level concentrations, the co-existence of nanoparticles with metal ions raises concerns for their enhanced bio toxicity. $\mathrm{TiO}_{2}$-facilitated transportation of $\mathrm{Cu}$, $\mathrm{Cd}$, and As has been reported in carp and Daphnia. ${ }^{80-83}$ Facilitated transport of adsorbed metals probably occurs when $\mathrm{TiO}_{2}$ nanoparticles enter from the water onto the gill surface and during the consumption of contaminated food sources. Tissues and cellular organelles with a low $\mathrm{pH}$, such as the stomach and the lysosome, may promote the release of such ions. Unfortunately, there is little data explaining the mechanism and extent that the nanoparticles may enable the transport of heavy metals into the environment.

This capability to adsorb trace amounts of chemicals (e.g. Fe) may initiate reactions (e.g. Fenton reactions) and alter the electronic state of the particle's subsequent catalytic reactions..$^{84}$ Titanium dioxide is a widely used inorganic component in formulations of stay-on cosmetics, including lipstick, sunscreen and face powder. The potential hazard of trace metal impurities in this matrix should be addressed, since the possible presence of metals raises the issue of nano- $\mathrm{TiO}_{2}$ acting as a magnifier for heavy metal (cations or complexes) pollution.

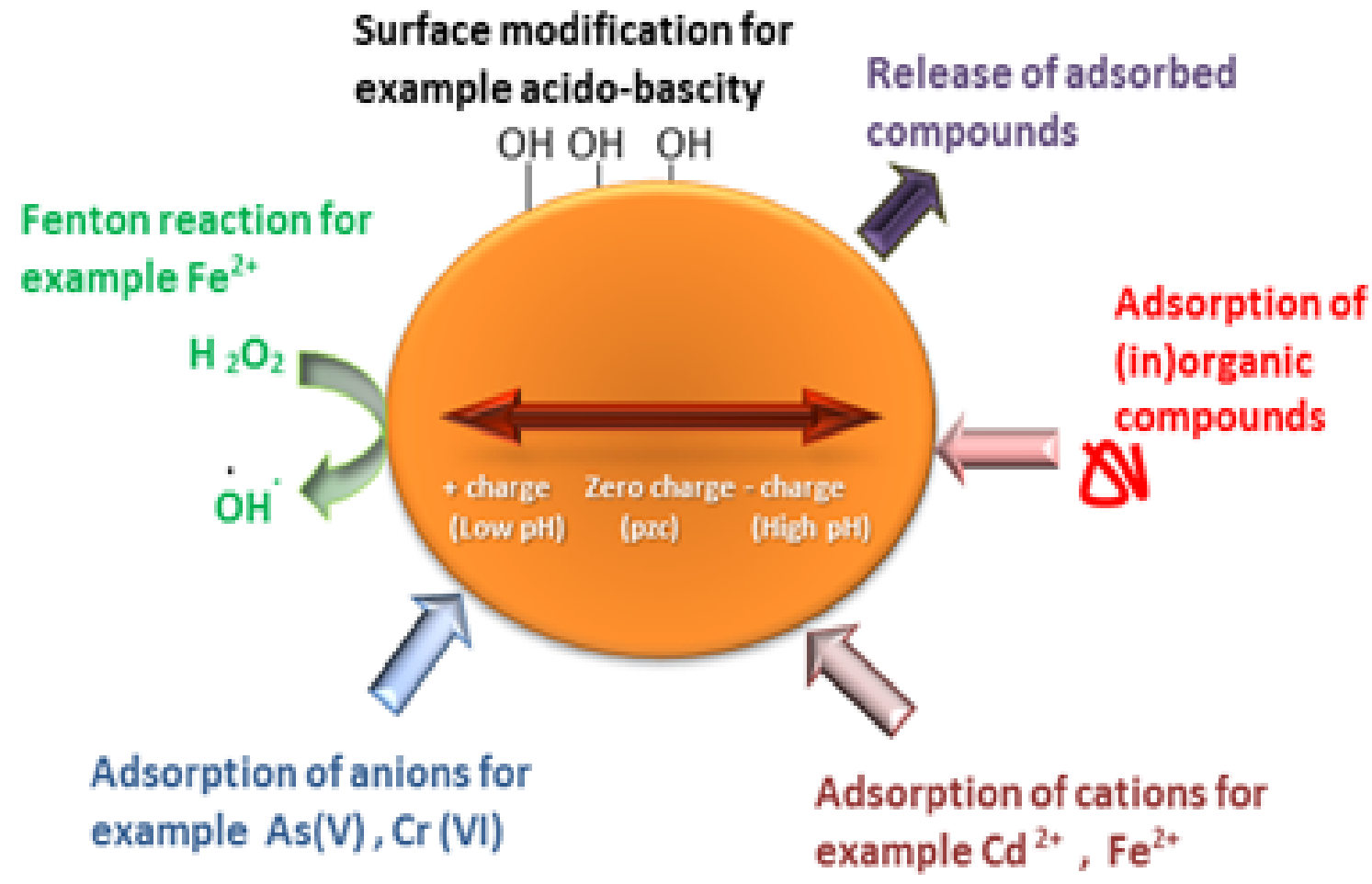

Figure 3 Influence of $\mathrm{pH}$ and surface charge on the adsorption of different ions and molecules.

\section{Solubility and surface impurities}

Enhanced photo catalysis cannot always be associated with toxicity. For example, it has been shown that the release of free cadmium from $\mathrm{Cd}$ Se nanoparticles is responsible for cytotoxicity in vitro ${ }^{85}$ rather than the photo activity or nanoscale. Similarly, Brunner et al. ${ }^{86}$ observed a relationship between material solubility and the cytotoxic response to a range of oxide nanoparticles, with more soluble compounds like $\mathrm{ZnO}$ showing greater acute toxicity than those with much lower solubility such as $\mathrm{TiO}_{2}$. The main toxicity of these nanoparticles was shown to be due to surface impurities, ${ }^{87}$ which often occur as a result of the synthesis process. The use of titanium alkoxides as synthesis precursors, ${ }^{88-91}$ as well as the use of acetic acid ${ }^{89}$ alcohol, ${ }^{92}$ oils,${ }^{93}$ and other organic solvents ${ }^{88,91,92}$ as reaction media are examples of such sources. Post-synthetic stabilization of nanoparticles through the use of surfactants also introduces extraneous material which may interfere with the accurate observation of the toxicity phenomenon.

\section{Radical formation}

Because $\mathrm{TiO}_{2}$ is an efficient photo catalyst in the presence of water, ROS (reactive oxygen species) or "free radicals" are produced as a consequence of UV light exposure. Quantitative studies for $\mathrm{OH}$ radical formation have been performed..$^{94}$ The formation of $\mathrm{OH}$ radicals from $\mathrm{TiO}_{2}$ varied according to crystal size and form. Irradiation of anatase produced large numbers of $\mathrm{OH}$ radicals in $\mathrm{TiO}_{2}$ in a dose-dependent response to $\mathrm{UV}$, but rutile $(90 \mathrm{~nm})$ showed less $\mathrm{OH}$ radical generation. $\mathrm{OH}$ radical generation was significantly influenced by crystal size, but the optimum size was different between both $\mathrm{TiO}_{2}$ forms. Non-UVinduced free radical formation at the surface of nano- $\mathrm{TiO}_{2}$ has been reported by Fenoglio et al. ${ }^{95}$ Although free radicals were not detected in solution, anatase and rutile-generated carbon center free radicals were found by the cleavage of sodium formate in the presence of $\mathrm{H}_{2} \mathrm{O}_{2}$. The presence of trace iron at the surface of $\mathrm{TiO}_{2}$ was cited as a possible cause for the generation of certain kinds of free radicals via a Fenton reaction. 


\section{Photo catalysis}

In a photo catalytic system, a photo-induced molecular transformation or reaction takes place at the surface of the catalyst. The photo catalytic reaction is initiated when a photo excited electron is promoted from the filled valence band $(V B)$ of the semiconductor photo catalyst to the empty conduction band $(C B)$, where the energy between the two bands is called the "band gap." The absorbed photon energy $(\mathrm{h} v)$, must or exceed the band gap of the semiconductor, to promote the electron and leave behind a positively charged hole in the valence band. Thus both the electron and whole pair $\left(\mathrm{e}^{-}+\mathrm{h}^{+}\right)$are generated (equation 3).

$$
\mathrm{TiO}_{2}+h v \rightarrow\left(e_{\mathrm{CB}}^{-}+h_{V B}^{+}\right) \mathrm{TiO}_{2} \ldots \ldots .(3)
$$

The photo generated electrons and holes that do not immediately recombine can migrate to the particle surface and participate in reduction and oxidation processes. Such reactions might include oxidation of adsorbed compounds, oxidative damage to cells, modification of enzymes and sensitive thiols, or transformation of metal ions to a higher or lower oxidation state (Figure 4). To achieve a higher photo activity, it is necessary to minimize the rate of the recombination process which will increase the lifetime of separated electron-hole pairs, such that more electron transfer can occur from the surface to the adsorbed species. ${ }^{96,97}$

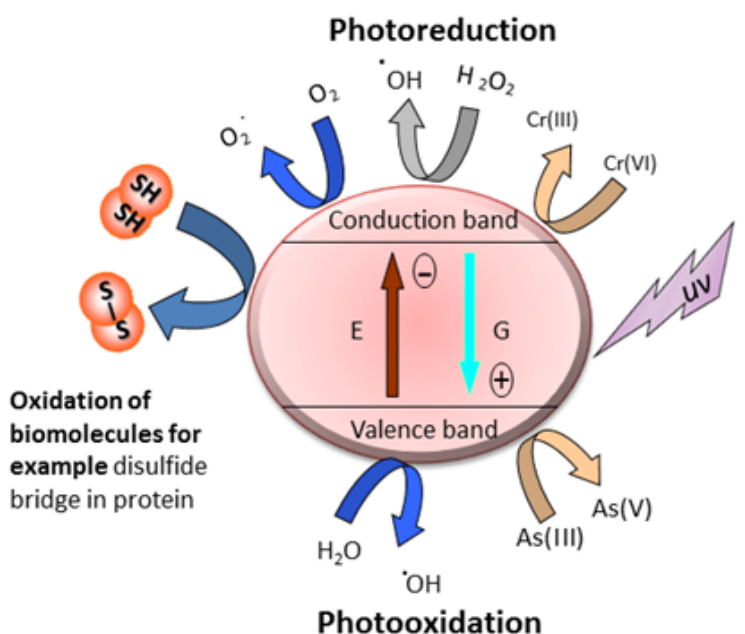

Figure 4 Photo catalytic transformation of different metal ions and molecules.

Photo activity is affected by a number of factors such as particle size, crystal structure, incident light intensity, solution $\mathrm{pH}$, and the particle preparation method. Crystal structure and particle size are considered to be the more important factors that determine photo activity. Many researchers have reported that anatase nanoparticles have a higher photo activity than rutile. ${ }^{27,98-100}$ Others have reported that anatase with a small amount of rutile has a higher photo activity than that of the pure anatase. ${ }^{101}$ It is interesting to note that sizedependent photo catalytic activity does not increase monotonically with decreasing size but rather passes through a maximum significantly below $100 \mathrm{~nm}$. Optimum sizes are thought to result from competing effects of the particle size on light absorption and scattering efficiency. However, as the particle size is lowered below a certain limit, surface recombination processes become dominant because most of the electrons and holes are generated close to the surface, and surface recombination is faster than the interfacial charge carrier transfer processes. This finding is probably why there exists an optimum particle size for maximum photo catalytic efficiency. ${ }^{38,96,101}$

\section{Photo catalytic transformation of organic compounds}

Photo catalytic decomposition of toxic and non-biodegradable organic compounds using $\mathrm{TiO}_{2}$ as a photo catalyst is an important component in the field of advanced oxidation technologies. ${ }^{96,102-104}$ Many publications report that test compounds are mineralized into harmless byproducts, but the measurement of compound disappearance is not sufficient to ensure the absence of by-products. The generation of a variety of organic intermediates (in some cases more toxic and persistent than the starting substrate) during heterogeneous photo catalysis has been noted if the treatment is not continued to complete mineralization. For example, increased toxicity of the byproduct has been observed for melamine, diclofenac, azo dyes, and other compounds during $\mathrm{TiO}_{2}$ photo catalysis. ${ }^{105-108}$

\section{Photo catalytic transformation of metal ions}

Photo catalysis can convert the ionic species into metals and deposit them over a semiconductor surface, or transform them into soluble species under thermodynamically favorable conditions. ${ }^{109-111}$ Metal ions can be reduced or oxidized by the photo catalytic activities of $\mathrm{TiO}_{2}$ (Figure 4).

If the solution contains a metal ion (e.g. $\mathrm{Hg}$ (II), $\mathrm{Cu}(\mathrm{II}), \mathrm{Cd}$ (II)) of appropriate redox potential, the conduction band electrons can reduce the species to a lower oxidation state (Equation 4). Alternatively, metal ions (e.g. $\mathrm{Pb}(\mathrm{II}), \mathrm{Mn}(\mathrm{II}), \mathrm{TI}(\mathrm{I}), \mathrm{Cr}(\mathrm{VI})$ ) can be oxidized by holes or hydroxyl radicals to a higher oxidation state (Equation 5).

$$
\begin{aligned}
& M^{\prime \prime}+\frac{r_{D}}{H O} \rightarrow M^{(\cdots+\cdots} \ldots \ldots . .(5) \\
& M^{n+}+\frac{h_{V B}^{+}}{H O} \rightarrow M^{(n+1)+} \ldots \ldots . .(5)
\end{aligned}
$$

The adsorption, desorption and photo catalytic transformation of toxic heavy metals by $\mathrm{TiO}_{2}$ may dramatically affect the facilitated transport ability of nanoparticles in different compartments of the environment. This ability of $\mathrm{TiO}_{2}$ has been exploited for the removal of heavy metals from wastewater, for example.

\section{Photocatalysis versus photostability}

Researchers have been interested in the modification of the electronic and optical properties of nano- $\mathrm{TiO}_{2}$ for its efficient use in water and air treatment and cosmetic formulations. Some researchers have attempted to enhance photo catalysis to decompose organic substances, solar cell production and hydrogen synthesis under visible light. Others have attempted to develop techniques to minimize the photo catalysis of nano- $\mathrm{TiO}_{2}$ without altering its UV screening ability for its use in cosmetics.

\section{Approaches to improve photo catalysis}

Surface spots on $\mathrm{TiO}_{2}$ nanoparticles can act as electrodes with both oxidation and reduction processes occurring on them. The surface states and the electron-hole pair recombination of $\mathrm{TiO}_{2}$ determine the overall quantum efficiency for interfacial charge transfer. The balance between the recombination and the trapping of charge carriers, followed by the competition between the recombination of the trapped 
carriers and the interfacial charge transfer ${ }^{96}$ are major factors in the efficiency. Therefore, improved charge separation and inhibition of charge carrier recombination is key to improving the overall quantum efficiency for interfacial charge transfer. ${ }^{112}$ Modification of particle properties by selective surface treatment ${ }^{96}$ is a common route to this goal.

The foremost limitation of $\mathrm{TiO}_{2}$ as a photo catalyst is the fact that it requires UV irradiation to function. The band gap (i.e. the amount of energy required to free the outer shell electron to become a mobile charge carrier) of anatase $\mathrm{TiO}_{2}$ is $3.2 \mathrm{eV}$ (equivalent to $387 \mathrm{~nm}$ and lower wavelengths), which makes the utilization of solar and indoor light inefficient for photo catalysis because only a small percentage of the available radiation can be used.

Visible light activity has been induced in $\mathrm{TiO}_{2}$ by surface modification using sensitization by dye, polymer, semiconductor particle coupling $\left(\mathrm{Bi}_{2} \mathrm{~S}_{3}, \mathrm{CdS}, \mathrm{CdSe}, \mathrm{V}_{2} \mathrm{O}_{5}\right)$, and band gap modification by doping (intentionally introducing impurities) with a transition metal ( $\mathrm{Fe}, \mathrm{V}, \mathrm{Cr}, \mathrm{Mn}, \mathrm{Co}, \mathrm{Ni}$ and $\mathrm{Cu}$ ) and nonmetals (halogen, $\mathrm{N}$, , S, B and C). ${ }^{26}$ Band gap tailoring by doping has been one of the most efficient and frequently used approaches. These modifications of $\mathrm{TiO}_{2}$ decrease the band gap energy or create new energy levels in the band gap (Figure 5A). An appropriate dopant metal (e.g. Mn and Fe ions) causes the absorption edge of the $\mathrm{TiO}_{2}$-based nano-composite to "red-shift" (i.e. to longer wavelengths) (Figure 5B), which makes the materials catalytically active in the visible light spectrum. When metal ion dopants are used, the modification does not depend solely on the type of dopant but also on its concentration and distribution within the particle. The visible light-sensitized nano- $\mathrm{TiO}_{2}$ particles are widely used in research on environmental cleanup technologies. It is quite reasonable to assume that loading nano- $\mathrm{TiO}_{2}$ with different chemical species may produce a completely different eco toxicological impact compared to unmodified particles.

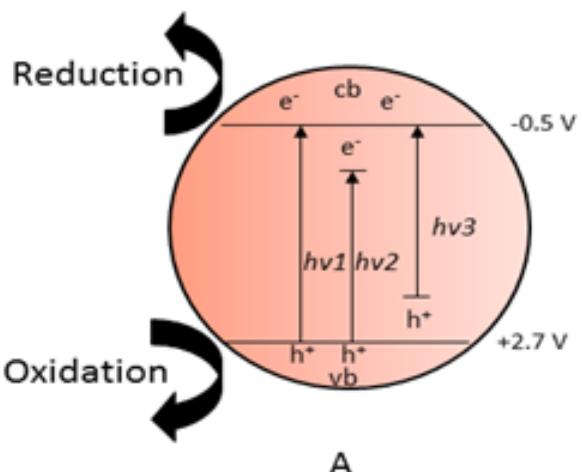

A

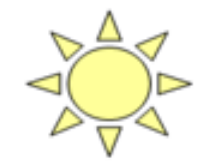

(Visible light)

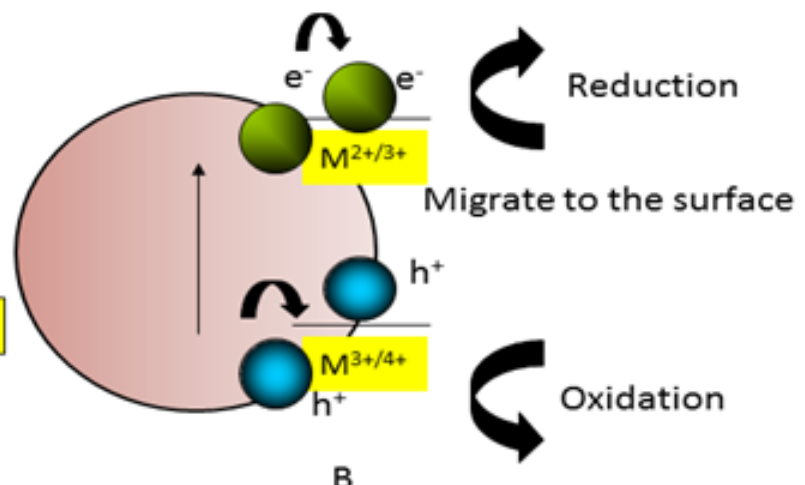

Figure 5A Photo catalysis under visible light Doping-induced intermediate band states in $\mathrm{TiO}_{2}$; hvl: pure $\mathrm{TiO}_{2}$; hv2: metal-doped TiO , and hv3: non-metal-doped $\mathrm{TiO}_{2}$.

Figure 5B Metal ion-doped nano- $\mathrm{TiO}_{2}$ photo catalyst.

In addition to UV light, visible light was shown to increase the toxicity of nano- $\mathrm{TiO}_{2}$ (carbon-doped $\mathrm{TiO}_{2}$ and $\mathrm{TiO}_{2}$ modified with platinum [IV] chloride complexes) towards bacteria and fungi. ${ }^{113}$ Independent of light, copper-doped nano- $\mathrm{TiO}_{2}$ particles are able to significantly reduce the growth of certain bacteria compared to copper ions alone. This may be the result of the particles penetrating the cell membrane and releasing copper ions inside the cell. ${ }^{114-117}$

\section{Approaches to reducing photo activity of nano-TiO2}

Because photo catalytic activity is one of the mechanisms for toxicity, it has been proposed to eliminate it by blocking the availability of reactive surface species. Much effort has been made to prepare titanium dioxide samples that are photo chemically inactive but still capable of protecting against UV radiation. Some sunscreens have used titanium dioxide particles that have been modified with inert coatings or doped with certain ions, presumably in an effort to prevent free radical damage to skin. However, current FDA regulations of $\mathrm{TiO}_{2}$ in topical sunscreens do not specify the crystalline form and do not require proof of photo stability (or lack of photo reactivity). ${ }^{118}$

\section{Surface coatings}

$\mathrm{TiO}_{2}$ adsorbs and scatters UV radiation, ${ }^{119}$ making it a desirable active ingredient in sunscreens where transparency, good dispersibility, and low photochemical and catalytic activities are the desired features. These qualities are acquired by modifying cosmetic-grade nano$\mathrm{TiO}_{2}$ particles in various ways without disturbing the sunscreen's ultraviolet-light ray-shielding properties. These modifications include organic (alkoxytitanates, silanes, and methyl polysiloxanes) and inorganic (alumina, silica, and zirconia) surface coatings. ${ }^{120-125}$ These modifications aim to minimize or eliminate the potential reactivity of photo activated $\mathrm{TiO}_{2}$ particles by quenching and/or reducing the reactive species generated before they can interact with the other ingredients in a formulation or with the skin itself. The labels on sunscreens generally do not indicate which crystal forms of titanium dioxide are present or what types of coating are used. The material used for the surface coatings, its thickness, its chemical purity, or the use of multiple coatings further increases the heterogeneity of the utilized $\mathrm{TiO}_{2}$ nanoparticles, ${ }^{126,127}$ The matrix in which the nano-sized $\mathrm{TiO}_{2}$ particle resides contributes another factor. The nanoparticles can, for example, be fixed in a matrix, such as the silica beads with nano-sized $\mathrm{TiO}_{2}$ particles from the Sunjin Chemical Corporation, or be bonded together via a surface coating. ${ }^{126}$

The presence of coatings also adds to the uncertainty about the effectiveness of efforts to reduce unwanted photo activity, and the durability of the coating layer during its life-cycle. ${ }^{128}$ Some researchers have characterized silica, zircon and alumina as charge transfer 
catalysts, ${ }^{129}$ which are solids that have the ability to trap reactive electrons $\left(\mathrm{e}^{-}\right)$and electropositive holes $\left(\mathrm{h}^{+}\right),{ }^{130}$ and their porous structures facilitate the access of reactant molecules to active surface sites. ${ }^{131}$ The researchers prepared nano composites of $\mathrm{SiO}_{2}, \mathrm{ZrO}_{2}$ and $\mathrm{Al}_{2} \mathrm{O}_{3}$ in $\mathrm{TiO}_{2},{ }^{132-135}$ which displayed improved photo catalytic activity versus pure $\mathrm{TiO}_{2} \cdot{ }^{135-139}$ The factors described above lead to a large diversity in nano-sized $\mathrm{TiO}_{2}$ particles used in cosmetic sunscreens. We must recognize that while many coatings are labeled as being environmentally labile or degradable ${ }^{16}$ the partial or complete collapse of the coated material may modify the electronic properties of $\mathrm{TiO}_{2}$ and an initially nontoxic material may become hazardous after shedding its coat.

\section{Metal-doped TiO2}

The properties of the nano- $\mathrm{TiO}_{2}$ can be changed as a consequence of production methods or by intentionally contaminating (doping) the crystal structure with other metals. ${ }^{140}$ For example, manganese doping is used by Oxonica- Croda to reduce the unwanted photo activity of the nano-sized $\mathrm{TiO}_{2}$ marketed under the name Optisol. ${ }^{141}$ Optisol is composed of ultrafine titanium dioxide-doped manganese $(0.7 \%))^{142} \mathrm{It}$ is not clearly defined whether this is given in atomic or weight percentage. On the other hand, many researchers reported that manganese-doped nano- $\mathrm{TiO}_{2}$ is able to absorb visible light and operate as a photo catalyst, even under visible light irradiation. ${ }^{143,144}$

The presence of metals may have the ability to modify the electronic state of $\mathrm{TiO}_{2}$. A metal particle on the surface may act as an electron trap, increasing the separation between the electron and whole and delaying recombination. A metal dopant may also increase whole mobility, which also diminishes the recombination rate. ${ }^{145}$ Iron oxide $\left(\mathrm{Fe}_{2} \mathrm{O}_{3}\right)$ pigments are added occasionally to give the cosmetic a brown tint to improve the appearance of the sun-care product. ${ }^{146,147}$ However, one should better understand the events occurring at the nanoscale when adding metals and their oxides to cosmetics that also contain semiconductor nanoparticles. Overall, studies show that modified $\mathrm{TiO}_{2}$ particles that are specifically developed and marketed for sun care, skin care, and color cosmetic formulations still retain photo catalytic activity. ${ }^{148-150}$ Coatings with alumina and doping with manganese have been suggested to be safe alternatives to other forms of modifications. ${ }^{148,151}$ Whether photo catalytic activity is still present during user application (i.e., inside a cosmetic formulation in the presence of other ingredients and applied to skin) is open to question. This results in more uncertainty, which forms a barrier to the assessment and management of the risks of nano materials.

\section{Interactions among bio-physicochemical variables}

Nanoparticles may undergo surface modification immediately after synthesis. ${ }^{152}$ The studies using only pristine nano- $\mathrm{TiO}_{2}$ particles may not be relevant for assessing the mechanism of toxicity and predicting behavior. In fact, proper attention needs to be given to the physicochemical properties, modifications and events occurring at the boundaries as a result of interactions (Figure 6). These events are determined by the physicochemical properties like size, shape, impurities, agglomeration, $\mathrm{pH}$, surface chemistry, coating, photo activity, and formation of reactive species (both ex-vivo and in vivo) by nano- $-\mathrm{TiO}_{2}$. The release of adsorbed substances and change in the agglomeration state of the nano- $\mathrm{TiO}_{2}$ inside the cell could initiate cytotoxicity and immune responses of varying degrees. Reactive oxygen species products, whether inside or outside the cell, can be key factors in nano- $\mathrm{TiO}_{2}$ toxicological effects. Before the internalization of the nano- $\mathrm{TiO}_{2}$ by a cell, photo catalytic activities may transform the initially harmless compounds into carbon-centered radicals $\left(\mathrm{R}^{*}\right.$, $\left.\mathrm{RO}^{*}, \mathrm{ROO}^{*}\right)$. Photo activation of certain biomolecules may contribute to nano- $\mathrm{TiO}_{2}$-mediated toxicity. ${ }^{153}$ Most reactions yielding adverse responses or inhibiting toxicity take place at the nano-biointerface where the particle surface, including all adsorbed matter, is in contact with the cell and tissue.

Proteins are viewed as the primary and most important player in mediating solid organism interactions. The proteins and salts which are included in the biological medium will be adsorbed onto nanoparticles, ${ }^{87}$ within a brief period of time. ${ }^{154}$ The adsorption of proteins onto nanoparticles is important for understanding their cytotoxicity. A full characterization of protein adsorption on a nano structured surface should consist of a controlled variation of the following parameters: nanoscale morphology, ${ }^{155} \mathrm{pH}$ and ionic composition of the surrounding medium, protein type and concentration. Curved nano particle surfaces provide extra flexibility and enhanced surface area for the adsorbed protein molecules compared to planar surfaces. ${ }^{156-158}$ When dispersed in culture medium, some metal oxide nanoparticles can absorb proteins such as serum albumin, in a manner referred to as a "protein corona". ${ }^{159-161}$ Moreover, the pre-treatment of $\mathrm{TiO}_{2}$ particles at $\mathrm{pH} 7$ with divalent ions such as $\mathrm{Ca}^{2+}$ and $\mathrm{Mg}^{2+}$ increased the adsorption significantly. ${ }^{162}$ The possible explanation could be the presence a negative charge on serum albumin at a neutral $\mathrm{pH}^{163}$ and the presence of a calcium binding site, with the albumin bound to $\mathrm{TiO}_{2}$ through $\mathrm{Ca}^{2+}$. The adsorption could be particle size and time dependent. ${ }^{164,165}$

When biomolecules such as albumin are adsorbed onto the surface of nano particles, there is an increased chance that a cell will not recognize them as foreign particles, and as a result they may be taken up into the cells in what is called the "Trojan horse" effect. ${ }^{166}$ However, the effects of the nano particle-adsorbed materials on toxicity are unclear. A number of studies focusing on heavy metal ion adsorption at the $\mathrm{TiO}_{2}-\mathrm{H}_{2} \mathrm{O}$ interface showed that adsorption depends on such parameters as the system $\mathrm{pH}$, the initial metal concentration, temperature, and both the phase and amount of nano- $\mathrm{TiO}_{2}$. Generally, the adsorption of most metal ions by $\mathrm{TiO}_{2}$ could also happen at physiological $\mathrm{pH}$ and temperature. ${ }^{167-171}$ Metal-loaded nanoparticles may enhance the intracellular trafficking of adsorbed metal ions, through take up and localization in the lysosomes. The low $\mathrm{pH}$ in the lysomes may cause the release of adsorbed metal ions resulting in the otherwise rare transport of metal ions in the cytosol. pH-triggered modification also includes destabilization of large agglomerates into smaller ones, and rupturing of the lysosome releases the nanoparticles into the cytosol. Additional interactions include mitochondrial effects, Genotoxicity, and apoptosis. These effects are more relevant to environmental toxicology where organism is directly exposed to these particles

\section{Nano-bio interface}

Transport of the nano materials to the cells precedes the materials' uptake, and can be modeled by convection, sedimentation and diffusion mechanisms. Transport is strongly influenced by the intrinsic physical factors like size, shape, surface charge, agglomeration and factors related to exposure like number concentration and time. Most of the reactions yielding adverse responses or inhibiting toxicity start at the nano-bio interface (i.e. where the particle surface, including all adsorbed matter, contacts the cells and tissues). ${ }^{7}$ The uptake 
mechanism is not well understood at present. Nanoparticles have been found within cells, either free-floating in the cytoplasm or enclosed by a membrane. ${ }^{172-174}$ The precise mechanism by which $\mathrm{TiO}_{2}$ crosses the selectively permeable barrier of the plasma membrane is a question that must be considered on an individual basis because different cells utilize different nanoparticles uptake pathways depending on variations in size, charge, and surface reactivity. Also, different uptake pathways are associated with different intracellular fates of the internalized nano materials. Phagocytosis is the predominant method of internalization employed by immune cells, such as macrophages and neutrophils. Endocytosis is present in almost every cell type and can proceed through four distinct pathways: (i) clathrin-mediated endocytosis, (ii) caveolin-mediated endocytosis, (iii) macropinocytosis, and (iv) theclathrin/caveolin-independent pathway. ${ }^{175}$ Not every cell possesses all mechanisms. In addition, passive uptakeis a possible mechanism of cellular entry for some small molecules.

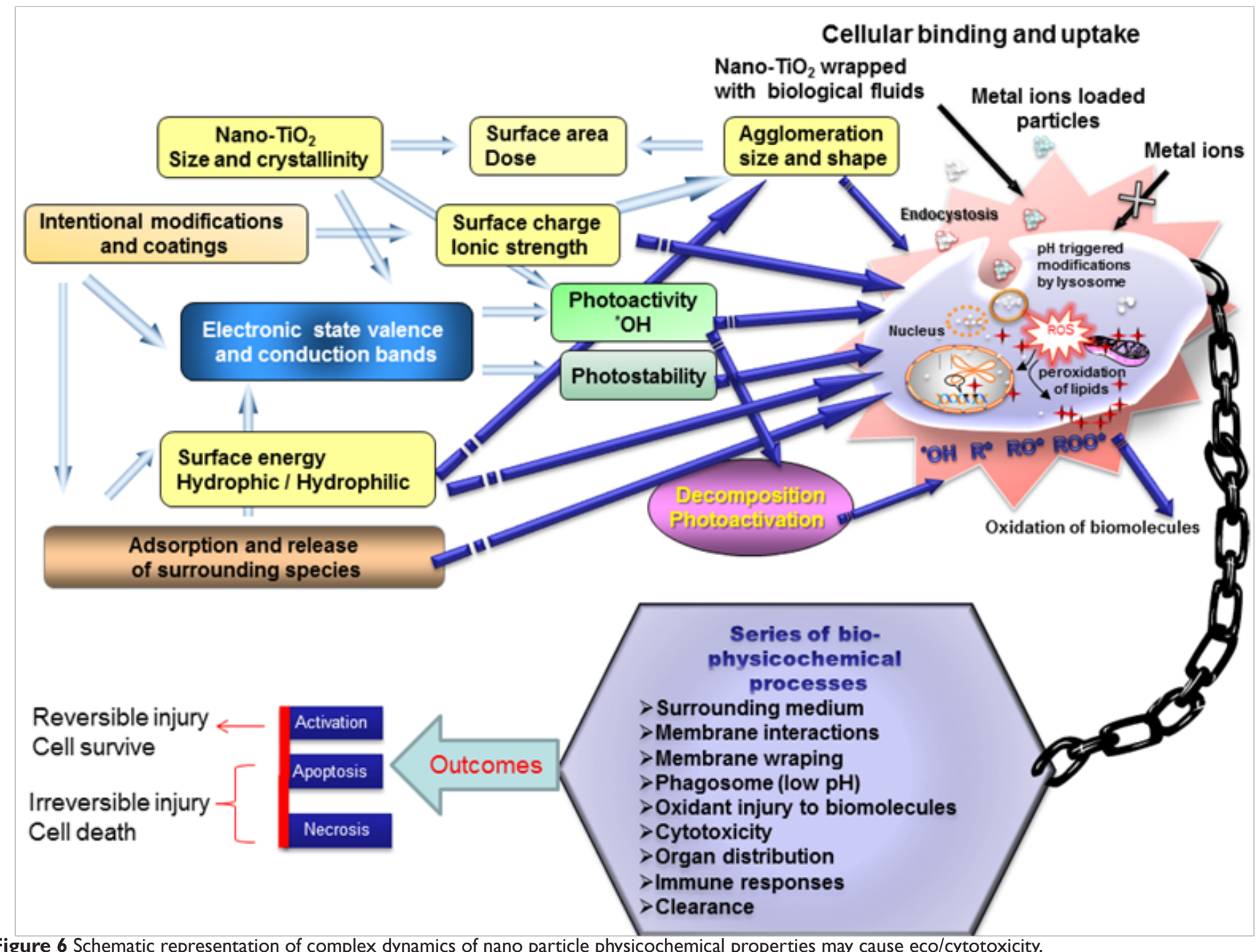

Figure 6 Schematic representation of complex dynamics of nano particle physicochemical properties may cause eco/cytotoxicity.

The predominant endocytic pathway in cells is clathrin-mediated endocytosis, which proceeds via the formation of clathrin-coated membrane invaginations that are eventually closed off to form clathrin-coated vesicles and endosomes. Endosomes formed in the clathrin pathway undergo acidification and are eventually destined for lysosomal degradation. The pathways of caveolin-mediated endocytosis and macropinocytosis have slower kinetics than the clathrin-mediated pathway, but the endosomes formed by these two pathways are not directed to the lysosomes. The fourth pathway is not well characterized and is known simply as the clathrin/ caveolin-independent pathway. ${ }^{176,177}$ Phagocytosis is apparently not a major contributor to nano particle uptake because the inhibition of phagocytosis using cytochalasin D (cytD) in macrophages abolished the uptake of micrometer-sized particles, but not of $0.2 \mu \mathrm{m}$ and $0.1 \mu \mathrm{m}$ sized particles. Geiser et al. ${ }^{178}$ noted that the intracellular nanoparticles were not membrane-enclosed and concluded that non-phagocytic and non-endocytic mechanisms might also be responsible for their uptake. Other reports have proposed that nanoparticles may be sequestered in endosomes, which could be the result of all three major pathways of endocytosis. ${ }^{179,180}$ In these studies, as in other nanoparticle uptake studies, there was a clear correlation between the nanoparticle localization in the cell, the "availability" of uptake pathways, and the cell type.

Early endosomes formed by the clathrin, caveolin, and macropinocytic processes pursue a defined pathway that leads to the formation of late endosomes. This formation is followed by sorting within multi vesicular bodies and, finally, fusion with degradative lysosomes. ${ }^{181,182}$ Notably, $\mathrm{TiO}_{2}$ nanoparticles have been localized in endosomes as well as to multi vesicular bodies. ${ }^{179}$ Several in vitro 
examinations concerning cellular responses induced by ultrafine $\mathrm{TiO}_{2}$ particles have been reported and mainly involve oxidative stress. These studies suggest that ROS are involved in the cytotoxic effects of $\mathrm{TiO}_{2}$ with two mechanisms, namely extra cellular ROS generation and intracellular ROS induction. Compared to photo excited $\mathrm{TiO}_{2}$ particles, the cytotoxic effect of non-photo excited $\mathrm{TiO}_{2}$ particles was lower. ${ }^{47,183}$ However, a change in certain physical and chemical properties led to a change in biological activity. ${ }^{3}$

\section{Influence of interactions with other materials}

Ex vivo testing determined that sunscreen nanoparticles remain on the surface of the skin in the stratum corneum among keratinized cells and do not reach the underlying viable cells. Moreover, the issue of the ROS generated by nanoparticles in sunscreens interacting with

Table I Nano-TiO, stimulated degradation of biomolecules other materials has also been raised, including the unattractive handand finger-shaped blemishes seen on coatings of pre-painted steel roofing sheets after they have been handled by workers wearing nano particle-containing sunscreens. ${ }^{149}$ Despite it is widely investigated photo catalytic properties, which indicate that large numbers of redox reactions can occur on the surface during UV exposure, titanium dioxide has always been considered to be a harmless and innocuous ingredient when added as a filter to sunscreen preparations or added as a whitener to many food and cosmetic products. ${ }^{184-186}$ A number of recent studies have revealed that under UVA irradiation, $\mathrm{TiO}_{2}$ may catalyze the degradation of biomolecules (Table 1). Additionally, they have the potential to destroy peroxidase enzymatic activity ${ }^{187}$ and cause in vitro photo toxicity. ${ }^{188,189}$ Several studies indicate that titanium dioxide extracted from commercial sunscreens is equally effective in causing DNA damage (Table 1).

\begin{tabular}{|c|c|c|}
\hline $\mathrm{TiO}_{2}$ particle & Experiment & Outcomes \\
\hline $\begin{array}{l}0.45 \mu \\
\text { Manatase }\end{array}$ & $\begin{array}{l}\text { Irradiation of solutions containing calf thymus } \\
\text { DNA and RNA isolated from human skin } \\
\text { fibroblast cells. }\end{array}$ & Significant levels of photo oxidation of nucleic acids were measured. ${ }^{164}$ \\
\hline $\begin{array}{l}\text { Extracted } \\
\text { From } \\
\text { Commercially } \\
\text { Available } \\
\text { Sunscreens }\end{array}$ & $\begin{array}{l}\text { Oxidation of organic material (phenol), DNA } \\
\text { plasmid and in vivo DNA tested. All experiments } \\
\text { conducted in sunlight-illuminated conditions. }\end{array}$ & $\begin{array}{l}\mathrm{TiO}_{2} \text { stimulates oxidation of organic materials (due to production of } \\
\text { hydroxyl radicals) and induces strand breaks in plasmid DNA and in } \\
\text { vivo (human fibroblasts). DNA damage decreased with the addition of } \\
\text { radical quenchers (mannitol and DMSO), illustrating oxidant-driven DNA } \\
\text { damage. }{ }^{162}\end{array}$ \\
\hline P25 & $\begin{array}{l}\text { The fate of nitrogen in various amino acids was } \\
\text { examined following their photo oxidative (and/ } \\
\text { or reductive) transformation catalyzed by UV-A } \\
\text { and UV-B illuminated aqueous } \mathrm{TiO}_{2} \text { dispersions. }\end{array}$ & $\begin{array}{l}\text { Nitrogen in the amino acids are photo converted predominantly into } \mathrm{NH}_{3} \\
\text { (analyzed as } \mathrm{NH}_{4}^{+} \text {), and to a lesser extent into } \mathrm{NO}_{3}^{-} \text {ions. }{ }^{100}\end{array}$ \\
\hline $\begin{array}{l}\text { Anatase or } \\
\text { Rutile }\end{array}$ & $\begin{array}{l}\text { Bovine serum albumin (BSA) protein nitration } \\
\text { (detected spectro photometrically and by } \\
\text { western blotting). Experiments conducted with } \\
\text { UV irradiation. }\end{array}$ & $\begin{array}{l}\text { Protein nitration was observed and identified as being in the crystal form } \\
\text { and light dependent. }{ }^{163}\end{array}$ \\
\hline
\end{tabular}

$\mathrm{TiO}_{2}$ can interact with organic compounds that are present in their vicinity; for example, reactive carbon-centered radicals are generated during the mineralization of organic sunscreen components. ${ }^{190,191}$ In light of these results, it is somewhat surprising that the possible interaction between sunscreen organic components and titanium dioxide has not been studied with the same enthusiasm as was done for the skin penetration studies. In order to properly investigate the photo toxicity of sun protection products, not only should the filters be considered but also the other components that despite being photo chemically inactive, may participate in the generation of harmful species, such as preservatives (isothiazoline family, parabens mixtures, and formaldehyde donors), anionic surfactants, oils, water or alcohol based gels, or antioxidants, which are all widely used in sunscreen preparation.

\section{Skin penetration}

Dermal absorption of chemicals must be considered during risk evaluation. ${ }^{192-194}$ The skin is the largest organ of the body and accounts for over $10 \%$ of the body's mass, and plays an important role as a barrier against the external environment. The skin functions in protection, maintaining homeostasis and metabolism. Four mechanisms of penetration across the skin have been identified and are dependent on the physicochemical properties of the compound. These mechanisms include an intercellular, a transcellular, and two trans appendageal (hair follicles and sweat glands) mechanisms. Several recently published reviews provide excellent overviews of the diffusion of micro- and nano sized $\mathrm{ZnO}$ and $\mathrm{TiO}_{2}$ through the skin. ${ }^{195-198}$ A large number of studies suggest that these particles do not penetrate human skin beyond the superficial layers of the stratum corneum. ${ }^{3,195-200}$ Skin exposure to nano particle-containing sunscreens leads to incorporation of $\mathrm{TiO}_{2}$ and $\mathrm{ZnO}$ in the stratum corneum, which may alter certain properties due to particle-particle, particle-skin, and skin-particle-light physicochemical interactions. ${ }^{195}$ Overall, the weight of scientific evidence suggests that insoluble nanoparticles used in sunscreens pose no or negligible risk to human health ${ }^{196,197,201-210}$ however there are some discrepancies in the results probably related to differences in techniques and methods, laboratory conditions, and the absence of standardized evaluation protocols.

The reason for these results is unclear based on the observation that most other nano particle types (polymers, metals and carbon nano tubes) permeate the skin. The answer may be that it is possible that the particle agglomeration, ${ }^{211,212}$ when combined with the particles' intrinsic hydrophobicity, allows particles to become trapped in the lipid lamella and remain until desquamation or sebaceous secretion 
removes them from follicles. Efficient transdermal drug delivery has been correlated with skin hydration. ${ }^{213,214}$ This finding indirectly suggests the importance of accessing the polar pathway in penetrating the skin barrier, which hinders hydrophobic particle penetration. There may be physicochemical factors other than size, surface charge, and surface energy that are important when evaluating nano material penetration (e.g. the nano particle mechanical properties) For example, recent findings in studies that measured the distribution profile of elastic and rigid vesicles $(115 \mathrm{~nm}$ diameter) in human skin identified that elastic particles penetrate deeper under identical conditions. ${ }^{215}$ Perhaps the particles must be able to fit through the stratum corneum, and metal oxide nanoparticles may be less compliant than metals of semiconductor QDs. Research findings demonstrate that the penetration of $\mathrm{TiO}_{2}$ is negligible in healthy skin. This is important, as nanoparticles appear to be unable to reach the living cells present within the deeper skin layers, and therefore their propensity for toxicity is anticipated to be minimal. Future studies should consider the fate of particles in skin models, taking into consideration that sunscreens are often applied to burnt, damaged, or diseased skin where the barrier function of the stratum corneum may be impaired. ${ }^{49,208}$ More research is needed to resolve this issue and to gain a quantitative understanding of the extent and mechanisms of nano particle skin penetration.

\section{Conclusion}

Most of the adverse effects, including inflammatory response, Genotoxicity, lipid peroxidation, oxidative stress and changes in enzyme activity have been attributed to the small size of $\mathrm{TiO}_{2}$ particles. Particle size does play a contributing role in toxicity, because reduced size corresponds to increased particle numbers and enhanced surface area for a given particle mass. However, the reactivity of the particle surface and interactions with the surrounding matrix can also lead to complex and unexpected phenomena arising from the interplay of many factors. Particle-cellular interactions and particle-environmental interactions can have a significant influence on reactivity modifications generating toxic species, with their subsequent impact on health and the environment. The large specific surface area of the nanoparticles is very effective for capturing low concentration chemical species such as metals. The presence of impurities not only influences the photo catalytic properties of $\mathrm{TiO}_{2}$, but may be helpful in the transportation and accumulation of trace elements in both cellular- and environmental-related studiesin which $\mathrm{pH}$ could play a very important role by the change of agglomerate size, and by adsorption and release of trace metals. The interaction between nano- $\mathrm{TiO}_{2}$ and a biological system and its surroundings are based on their inherent physicochemical properties and the modifications made to the nano- $\mathrm{TiO}_{2}$. A largely ignored aspect in the literature is the photo catalytic ability of nano- $\mathrm{TiO}_{2}$ to mineralize organic components and, in the case of partial decomposition, to form reactive intermediates. These reactive species have the potential to cause oxidative injury $e x$ vivo or in environmental-related scenarios. It becomes a considerable challenge for nanotoxicologists to determine whether this toxicity is due simply to size or to the reactivity of nanoparticles with the surrounding medium. Alternatively, the nanoparticles may only be playing a role in the transportation and accumulation of certain chemical species, or the toxicity may be the combination of different processes. The challenge for toxicologists is to identify key factors or tests by which nano particle toxicity can be measured or predicted, and these data must be reproducible in other laboratories. Multidisciplinary efforts will be required to fully understand the underlying mechanism of nano material toxicity.
Careful examination of the classical (particle size, surface area and dose) and non-classical interactions (size-related properties and altered reactivity) of nano- $\mathrm{TiO}_{2}$ may be helpful in developing safer consumer goods, such as sunscreen. Nano-based sunscreens contain particles in the range of 10 to $100 \mathrm{~nm}^{200}$ and contain both anatase and rutile crystals, either alone or in combination. ${ }^{216}$ Most studies have revealed the absence of cutaneous penetration. Smaller, doped, coated, and more dispersed $\mathrm{TiO}_{2}$ particles were demonstrated to have superior UV attenuation, due to enhanced UV scattering. The problem of undesirable photo catalysis is addressed by applying surface treatments to the crystals, selecting a less photo reactive form (rutile), or adding antioxidant ingredients to the formula. Recent research has identified that the surface coatings on nano- $\mathrm{TiO}_{2}$ in many sunscreens may be unstable or ineffective. ${ }^{149}$ However, doping rutile nano- $\mathrm{TiO}_{2}$ with manganese was reported to increase UV absorption, reduce free radical generation, and increase its free radical-scavenging behavior. ${ }^{142,151}$ Perhaps an important question is whether regulatory authorities should be discriminating between anatase and rutile titanium dioxide particles, or between doped and un-doped particles, in sunscreens. There is an urgent need for an international consensus for determining the status and safety requirements of these products and their ingredients.

\section{Acknowledgements}

None.

\section{Conflict of interest}

The author declares no conflict of interest.

\section{References}

1. Colvin VL. The potential environmental impact of engineered nanomaterials. Nat Biotechnol. 2003;21(10):1166-1170.

2. Dreher KL. Health and environmental impact of nanotechnology:toxicological assessment of manufactured nanoparticles. Toxicol Sci. 2004;77(1):3-5.

3. Oberdorster G, Oberdorster E, Oberdorster J. Nanotoxicology: An emerging discipline evolving from studies of ultrafine particles. Environ Health Perspect. 2005;113(7):823-839.

4. Nel A, Xia T, Madler L, et al. Toxic potential of materials at the nanolevel. Science. 2006;311(5761):622-627.

5. Powers KW, Brown SC, Krishna VB, et al. Research strategies for safety evaluation of nanomaterials. Part VI. Characterization of nanoscale particles for toxicological evaluation. Toxicol Sci. 2006;90(2):296-303.

6. Tiede K, Boxall AB, Tear SP, et al. Detection and characterization of engineered nanoparticles in food and the environment. Food Addit Contam Part A Chem Anal Control Expo Risk Assess. 2008;25(7):795821

7. Nel AE, Madler L, Velegol D, et al. Understanding biophysicochemical interactions at the nano-bio interface. Nat Mater. 2009;8(7):543-557.

8. Robichaud CO, Tanzil D, Weilenmann U, et al. Relative risk analysis of several manufactured nanomaterials: An insurance industry context. Environ Sci Technol. 2005;39(22):8985-8994.

9. Mueller NC, Nowack B. Exposure modeling of engineered nanoparticles in the environment. Environ Sci Technol. 2008;42(12):4447-4453.

10. Bystrzejewska-Piotrowska G, Golimowski J, Urban PL. Nanoparticles: Their potential toxicity, waste and environmental management. Waste Manag. 2009;29(9):2587-2595. 
11. Christensen FM, Johnston $\mathrm{HJ}$, Stone V, et al. Nano- $-\mathrm{TiO}_{2}$-feasibility and challenges for human health risk assessment based on open literature. Nanotoxicology. 2011;5(2):110-124.

12. Ophus EM, Rode L, Gylseth B, et al. Analysis of titanium pigment in human-lung tissue. Scand J Work Environ Health. 1979;5(3):290-296.

13. Pott F, Roller M. Carcinogenicity study with nineteen granular dusts in rats. Eur J Oncol. 2005;10:249-81.

14. Baan R, Straif K, Grosse Y, et al. Carcinogenicity of carbon black, titanium dioxide, and talc. Lancet Oncol. 2006;7(4):295-296.

15. Nakata K, Fujishima A. $\mathrm{TiO}_{2}$ photocatalysis:Design and applications. Journal of Photochemistry and Photobiology C: Photochemistry Reviews. 2012;13(3):169-189.

16. Labille J, Feng J, Botta C, et al. Aging of $\mathrm{TiO}_{2}$ nanocomposites used in sunscreen. Dispersion and fate of the degradation products in aqueous environment. Environ Pollut. 2009;158(12):3482-3489.

17. Baram N, Starosvetsky D, Starosvetsky J, et al. Photocatalytic inactivation of microorganisms using nanotubular $\mathrm{TiO}_{2}$. Applied Catalysis B: Environmental. 2011;101(3-4):212-219.

18. Guo MZ, Ling TC, Poon CS. $\mathrm{TiO}_{2}$-based self-compacting glass mortar:Comparison of photocatalytic nitrogen oxide removal and bacteria inactivation. Building and Environment. 2012;53:1-6.

19. Wang Q, An N, Bai Y, et al. High photocatalytic hydrogen production from methanol aqueous solution using the photocatalysts $\mathrm{CuS} / \mathrm{TiO}_{2}$. International Journal of Hydrogen Energy. 2013;38(25):10739-10745.

20. Lianos P. Production of electricity and hydrogen by photocatalytic degradation of organic wastes in a photoelectrochemical cell:the concept of the Photofuelcell:A review of a re-emerging research field. $J$ Hazard Mater. 2011;185(2-3):575-590.

21. Malato S, Fernandez-Ibanez P, Maldonado MI, et al. Solar Photocatalytic Processes:Water Decontamination and Disinfection. In: Steven LS, editor. New and Future Developments in Catalysis. Netherlands: Elsevier; 2013. p. 371-393.

22. Tayade RJ, Kulkarni RG, Jasra RV. Photocatalytic Degradation of Aqueous Nitrobenzene by Nanocrystalline $\mathrm{TiO}_{2}$. Ind Eng Chem Res. 2006;45(3):922-927.

23. Hashimoto K, Irie $\mathrm{H}$, Fujishima $\mathrm{A}$. $\mathrm{TiO}_{2}$ Photocatalysis: A historical overview and future prospects. Jpn J Appl Phys. 2005;44(12):82698285.

24. Murat K, Zekiye C. A quantum mechanical approach to $\mathrm{TiO}_{2}$ photocatalysis. Journal of Advanced Oxidation Technologies. 2009;12(1):37-46.

25. Teleki A, Bjelobrk N, Pratsinis SE. Continuous surface functionalization of flame-made $\mathrm{TiO}_{2}$ Nanoparticles. Langmuir. 2010;26(8):5815-5822.

26. Rehman S, Ullah R, Butt AM, et al. Strategies of making $\mathrm{TiO}_{2}$ and $\mathrm{ZnO}$ visible light active. J Hazard Mater. 2009;170(2-3):560-569.

27. Sclafani A, Herrmann JM. Comparison of the Photoelectronic and Photocatalytic Activities of Various Anatase and Rutile Forms of Titania in Pure Liquid Organic Phases and in Aqueous Solutions. J Phys Chem. 1996;100(32):13655-13661.

28. Saquib M, Muneer $\mathrm{M}$. $\mathrm{TiO}_{2}$-mediated photocatalytic degradation of a triphenylmethane dye (gentian violet), in aqueous suspensions. Dyes and Pigments. 2003;56(1):37-49.

29. Kim TK, Lee MN, Lee SH, et al. Development of surface coating technology of $\mathrm{TiO}_{2}$ powder and improvement of photocatalytic activity by surface modification. Thin Solid Films. 2005;475(1-2):171-177.

30. $\mathrm{Mu} \mathrm{S}$, Long $\mathrm{Y}$, Kang SZ, et al. Surface modification of $\mathrm{TiO}$ nanoparticles with a $\mathrm{C}_{60}$ derivative and enhanced photocatalytic activity for the reduction of aqueous $\mathrm{Cr}(\mathrm{VI})$ ions. Catalysis Communications. 2010;11(8):741-744.
31. Huang J, Wen S, Liu J, et al. Band gap narrowing of $\mathrm{TiO}_{2}$ by compensated codoping for enhanced photocatalytic activity. Journal of Natural Gas Chemistry. 2012;21(3):302-307.

32. Tyner KM, Wokovich AM, Godar DE, et al. The state of nano-sized titanium dioxide $\left(\mathrm{TiO}_{2}\right)$ may affect sunscreen performance. Int $J$ Cosmet Sci. 2011;33(3):234-244.

33. Gruere GP. Labeling nano-enabled consumer products. Nano Today. 2011;6(2):117-121.

34. Aschberger K, Micheletti C, Sokull-Kluttgen B, et al. Analysis of currently available data for characterising the risk of engineered nanomaterials to the environment and human health-lessons learned from four case studies. Environ Int. 2011;37(6):1143-1156.

35. Cross SE, Innes B, Roberts MS, et al. Human skin penetration of sunscreen nanoparticles: In-vitro assessment of a novel micronized zinc oxide formulation. Skin Pharmacol Physiol. 2007;20(3):148-154.

36. DeLouise L, Mortensen L, Elder A. Breeching Epithelial BarriersPhysiochemical Factors Impacting Nanomaterial Translocation and Toxicity. Safety of Nanoparticles Nanostructure Science and Technology. 2009:33-62.

37. Klein J. Probing the interactions of proteins and nanoparticles. Proc Natl Acad Sci USA. 2007;104(7):2029-2030.

38. Auffan M, Rose J, Bottero JY, et al. Towards a definition of inorganic nanoparticles from an environmental, health and safety perspective. Nat Nanotechnol. 2009;4(10):634-641.

39. Rao CNR, Rao KJ. Phase transitions in solids: an approach to the study of the chemistry and physics of solids. USA: McGraw-Hill; 1978.

40. Bojinova A, Kralchevska R, Poulios I, et al. Anatase/rutile $\mathrm{TiO}_{2}$ composites:Influence of the mixing ratio on the photocatalytic degradation of Malachite Green and Orange II in slurry. Materials Chemistry and Physics. 2007;106(2-3):187-192.

41. Renwick LC, Donaldson K, Clouter A. Impairment of alveolar macrophage phagocytosis by Ultrafine Particles. Toxicol Appl Pharmacol. 2001;172(2):119-127.

42. Donaldson K, Brown D, Clouter A, et al. The pulmonary toxicology of ultrafine particles. $J$ Aerosol Med. 2002;15(2):213-220.

43. Renwick LC, Brown D, Clouter A, et al. Increased inflammation and altered macrophage chemotactic responses caused by two ultrafine particle types. Occup Environ Med. 2004;61(5):442-447.

44. Ji J, Long Z, Lin D. Toxicity of oxide nanoparticles to the green algae Chlorella sp. Chemical Engineering Journal. 2011;170(2-3):525-530.

45. Clement L, Hurel C, Marmier N. Toxicity of $\mathrm{TiO}_{2}$ nanoparticles to cladocerans, algae, rotifers and plants-Effects of size and crystalline structure. Chemosphere. 2013;90(3):1083-1090.

46. Jiang J, Oberdorster G, Elder A, et al. Does Nanoparticle Activity Depend upon Size and Crystal Phase? Nanotoxicology. 2008;2(1):33-42.

47. Sayes CM, Wahi R, Kurian PA, et al. Correlating nanoscale titania structure with toxicity: A cytotoxicity and inflammatory response study with human dermal fibroblasts and human lung epithelial cells. Toxicol Sci. 2005;92(1):174-185.

48. Jefferson DA. The surface activity of ultrafine particles. Philosophical Transactions A. 2000;358(1775):2683-2692.

49. Borm P, Robbins D, Haubold, et al. The potential risks of nanomaterials:a review carried out for ECETOC. Part Fibre Toxicol. 2006;3:11.

50. Choi HS, Liu W, Misra P, et al. Renal clearance of quantum dots. Nat Biotechnol. 2007;25(10):1165-1170.

51. Liang XJ, Chen C, Zhao Y, et al. Biopharmaceutics and therapeutic potential of engineered nanomaterials. Curr Drug Meta. 2008;9(8):697709 
52. Chen HW, Su SF, Chien CT, et al. Titanium dioxide nanoparticles induce emphysema-like lung injury in mice. FASEB J. 2006;20(13):2393-2395.

53. Wang J, Zhou G, Chen C, et al. Acute toxicity and biodistribution of different sized titanium dioxide particles in mice after oral administration. Toxicol Lett. 2007;168(2):176-185.

54. Gurr JR, Wang AS, Chen $\mathrm{CH}$, et al. Ultrafine titanium dioxide particles in the absence of photoactivation can induce oxidative damage to human bronchial epithelial cells. Toxicology. 2005;213(1-2):66-73.

55. Kang SJ, Kim BM, Lee YJ, et al. Titanium dioxide nanoparticles trigger p53-mediated damage response in peripheral blood lymphocytes. Environ Mol Mutagen. 2008;49(5):399-405.

56. Oberdurster G. Toxicology of ultrafine particles: in vivo studies. Philosophical Transactions A. 2000;358(1775):2719-2740.

57. Warheit DB. Debunking some misconceptions about nanotoxicology Nano Lett. 2010;10(12):4777-4782.

58. Tsuji JS, Maynard AD, Howard PC, et al. Research strategies for safety evaluation of nanomaterials, Part IV: risk assessment of nanoparticles. Toxicol Sci. 2006;89(1):42-50.

59. Warheit DB, Webb TR, Sayes CM, et al. Pulmonary instillation studies with nanoscale $\mathrm{TiO}_{2}$ rods and dots in rats: Toxicity is not dependent upon particle size and surface area. Toxicol Sci. 2006;91(1):227-236.

60. Oberdorster G, Stone V, Donaldson K. Toxicology of nanoparticles: A historical perspective. Nanotoxicology. 2007;1(1):2-25.

61. Jiang JK, Oberdorster G, Biswas P. Characterization of size, surface charge, and agglomeration state of nanoparticle dispersions for toxicological studies. Journal of Nanoparticle Research. 2009;11(1):7789

62. Fischer HC, Chan WC. Nanotoxicity: the growing need for in vivo study Curr Opin Biotechnol. 2007;18(6):565-571.

63. Zahr AS, Davis CA, Pishko MV. Macrophage uptake of core-shell nanoparticles surface modified with poly(ethylene glycol). Langmuir. 2006;22(19):8178-8185.

64. Scheuplein RJ, Blank IH. Mechanism of percutaneous absorption. IV. Penetration of nonelectrolytes (alcohols) from aqueous solutions and from pure liquids. J Invest Dermatol. 1973;60(5):286-296.

65. Morterra C. An infrared spectroscopic study of anatase properties. Part 6.-Surface hydration and strong Lewis acidity of pure and sulphatedoped preparations. J Chem Soc Faraday Trans1. 1988;84(5):16171637

66. Turchi CS, Ollis DF. Photocatalytic degradation of organic water contaminants: Mechanisms involving hydroxyl radical attack. Journal of Catalysis. 1990;122(1):178-192.

67. Jaffrezic-Renault N, Pichat P, Foissy A, et al. Study of the effect of deposited platinum particles on the surface charge of titania aqueous suspensions by potentiometry, electrophoresis, and labeled-ion adsorption. J Phys Chem. 1986;90(12):2733-2738.

68. Dutta PK, Ray AK, Sharma VK, et al. Adsorption of arsenate and arsenite on titanium dioxide suspensions. J Colloid Interface Sci. 2004;278(2):270-275.

69. Kosmulski M. pH-dependent surface charging and points of zero charge. IV. Update and new approach. J Colloid Interface Sci. 2009;337(2):439448.

70. Jezequel $\mathrm{H}$, Chu KH. Enhanced adsorption of arsenate on titanium dioxide using $\mathrm{Ca}$ and $\mathrm{Mg}$ ions. Environmental Chemistry Letters. 2005;3(3):132-135.

71. Vasileva E, Hadjiivanov K, Mandjukov P. Adsorption of $\mathrm{Cr}^{6+}$ oxo anions on pure and peroxide-modified $\mathrm{TiO}_{2}$ (anatase). Colloids and Surfaces A: Physicochemical and Engineering Aspects. 1994;90(1):9-15.
72. Kyung H, Lee J, Choi W. Simultaneous and synergistic conversion of dyes and heavy metal ions in aqueous $\mathrm{TiO}_{2}$ suspensions under visiblelight illumination. Environ Sci Technol. 2005;39(7):2376-2382.

73. Giammar DE, Maus CJ, Xie L. Effects of particle size and crystalline phase on lead adsorption to titanium dioxide nanoparticles. Environmental Engineering Science. 2007;24(1):85-95.

74. Hang YP, Qin YC, Jiang ZC, et al. Study on the adsorption Behavior of $\mathrm{Ga}$, In and $\mathrm{Tl}$ on nanometer-size titanium dioxide by ICP-AES. Guang Pu Xue Yu Guang Pu Fen Xi. 2005;25(7):1131-1134.

75. Liang $\mathrm{P}$, Qin $\mathrm{Y}, \mathrm{Hu} \mathrm{B}$, et al. Study of the adsorption behavior of heavy metal ions on nanometer-size titanium dioxide with ICP-AES. Fresenius J Anal Chem. 2000;368(6):638-640.

76. Kanna M, Wongnawa S, Sherdshoopongse P, et al. Adsorption behavior of some metal ions on hydrated amorphous titanium dioxide surface. Songklanakarin J Sci Technol. 2005;27(5):1017-1026

77. Engates KE, Shipley HJ. Adsorption of $\mathrm{Pb}, \mathrm{Cd}, \mathrm{Cu}, \mathrm{Zn}$, and $\mathrm{Ni}$ to titanium dioxide nanoparticles:effect of particle size, solid concentration, and exhaustion. Environ Sci Pollut Res Int. 2011;18(3):386-395.

78. Dou B, Dupont V, Pan W, et al. Removal of aqueous toxic $\mathrm{Hg}$ (II) by synthesized $\mathrm{TiO}_{2}$ nanoparticles and $\mathrm{TiO}_{2} /$ montmorillonite. Chemical Engineering Journal. 2011;166(2):631-638.

79. Duran C, Gundogdu A, Bulut VN, et al. Solid-phase extraction of $\mathrm{Mn}(\mathrm{II}), \mathrm{Co}(\mathrm{II}), \mathrm{Ni}(\mathrm{II}), \mathrm{Cu}(\mathrm{II}), \mathrm{Cd}(\mathrm{II})$ and $\mathrm{Pb}(\mathrm{II})$ ions from environmenta samples by flame atomic absorption spectrometry (FAAS). $J$ Hazard Mater. 2007;146(1-2):347-355.

80. Zhang X, Sun H, Zhang Z, et al. Enhanced bioaccumulation of cadmium in carp in the presence of titanium dioxide nanoparticles. Chemosphere. 2007;67(1):160-166.

81. Sun HW, Zhang X, Niu Q, et al. Enhanced accumulation of arsenate in carp in the presence of titanium dioxide nanoparticles. Water Air and Soil Pollution. 2007;178(1-4):245-254.

82. Fan W, Cui M, Liu H, et al. Nano-TiO enhances the toxicity of copper in natural water to Daphnia magna. Environ Pollut. 2011;159(3):729-734.

83. Sun $\mathrm{H}$, Zhang $\mathrm{X}$, Zhang $\mathrm{Z}$, et al. Influence of titanium dioxide nanoparticles on speciation and bioavailability of arsenite. Environ Pollut. 2009;157(4):1165-1170.

84. Gogniat $\mathrm{G}$, Dukan $\mathrm{S}$. $\mathrm{TiO}_{2}$ photocatalysis causes DNA damage via Fenton reaction-generated hydroxyl radicals during the recovery period. Appl Environ Microbiol. 2007;73(23):7740-7743.

85. Takahashi J, Misawa M. Analysis of Potential Radiosensitizing Materials for X-Ray-Induced Photodynamic Therapy. NanoBiotechnology. 2007;3(2):116-126.

86. Brunner TJ, Wick P, Manser P, et al. In vitro cytotoxicity of oxide nanoparticles:comparison to asbestos, silica, and the effect of particle solubility. Environ Sci Technol. 2006;40(14):4374-4381.

87. Horie M, Kato H, Fujita K, et al. In Vitro evaluation of cellular response induced by manufactured nanoparticles. Chem Res Toxicol. 2012;25(3):605-619.

88. Kambe S, Nakade S, Wada Y, et al. Effects of crystal structure, size, shape and surface structural differences on photo-induced electron transport in $\mathrm{TiO}_{2}$ mesoporous electrodes. J Mater Chem. 2002;12(3):723-728.

89. Chou TP, Zhang Q, Russo B, et al. Titania particle size effect on the overall performance of dye-sensitized solar cells. J Phys Chem. 2007;111(17):6296-6302.

90. Addamo M, Augugliaro V, Di Paola A, et al. Preparation, Characterization, and Photoactivity of Polycrystalline Nanostructured TiO 2 Catalysts. J Phys Chem. 2004;108(10):3303-3310

91. Tian B, Chen F, Zhang J, et al. Influences of acids and salts on the crystalline phase and morphology of $\mathrm{TiO}_{2}$ prepared under ultrasound irradiation. J Colloid Interface Sci. 2006;303(1):142-148. 
92. Li G, Li L, Boerio-Goates J, et al. High purity anatase $\mathrm{TiO}_{2}$ nanocrystals: near room-temperature synthesis, grain growth kinetics, and surface hydration chemistry. J Am Chem Soc. 2005;127(24):8659-8666.

93. Mori Y, Okastu Y, Tsujimoto Y. Titanium Dioxide Nanoparticles Produced in Water-in-oil Emulsion. Journal of Nanoparticle Research. 2001;3(2-3):219-225

94. Uchino T, Tokunaga $\mathrm{H}$, Ando M, et al. Quantitative determination of $\mathrm{OH}$ radical generation and its cytotoxicity induced by $\mathrm{TiO}_{2}-\mathrm{UVA}$ treatment. Toxicol in Vitro. 2002;16(5):629-635.

95. Fenoglio I, Greco G, Livraghi S, et al. Non-UV-induced radical reactions at the surface of $\mathrm{TiO}_{2}$ nanoparticles that may trigger toxic responses. Chemistry. 2009;15(18):4614-4621.

96. Hoffmann MR, Martin ST, Choi W, et al. Environmental Applications of Semiconductor Photocatalysis. Chem Rev. 1995;95(1):69-96.

97. Kominami H, Kato J, Takada Y, et al. Novel synthesis of microcrystalline titanium (IV) oxide having high thermal stability and ultra-high photocatalytic activity:thermal decomposition of titanium(IV) alkoxide in organic solvents. Catalysis Letters. 1997;46(3-4):235-240.

98. Nishimoto S, Ohtani B, Kajiwara H, et al. Correlation of the crystal structure of titanium dioxide prepared from titanium tetra-2-propoxide with the photocatalytic activity for redox reactions in aqueous propan-2ol and silver salt solutions. J Chem Soc Faraday Trans. 1985;181(1):6168.

99. Fox MA, Dulay MT. Heterogeneous photocatalysis. Chem Rev. 1993;93(1):341-357.

100. Jung KY, Park SB. Anatase-phase titania: preparation by embedding silica and photocatalytic activity for the decomposition of trichloroethylene. Journal of Photochemistry and Photobiology A Chemistry. 1999;127(1-3):117-122.

101. Jang HD, Kim SK, Kim SJ. Effect of Particle Size and Phase Composition of Titanium Dioxide Nanoparticles on the Photocatalytic Properties. Journal of Nanoparticle Research. 2001;3(2-3):141-147.

102. Bhatkhande DS, Pangarkar VG, Beenackers AA. Photocatalytic degradation for environmental applications - a review. Journal of Chemical Technology \& Biotechnology. 2002;77(1):102-116.

103. Bauer R, Waldner G, Fallmann H, et al. The photo-fenton reaction and the $\mathrm{TiO}_{2} / \mathrm{UV}$ process for waste water treatment - novel developments. Catalysis Today. 1999;53(1):131-144.

104. Beydoun D, Amal R, Low G, et al. Role of Nanoparticles in Photocatalysis. Journal of Nanoparticle Research. 1999;1(4):439-458.

105. Chebli D, Fourcade F, Brosillon S, et al. Supported photocatalysis as a pre-treatment prior to biological degradation for the removal of some dyes from aqueous solutions; Acid Red 183, Biebrich Scarlet, Methyl Red Sodium Salt, Orange II. Journal of Chemical Technology and Biotechnology. 2010;85(4):555-563.

106. Bozzi A, Dhananjeyan M, Guasaquillo I, et al. Evolution of toxicity during melamine photocatalysis with $\mathrm{TiO}_{2}$ suspensions. Journal of Photochemistry and Photobiology A: Chemistry. 2004;162(1):179-185.

107. Rizzo L, Meric S, Kassinos D, et al. Degradation of diclofenac by TiO photocatalysis: UV absorbance kinetics and process evaluation through a set of toxicity bioassays. Water Res. 2009;43(4):979-988.

108. Bolduc L, Anderson WA. Enhancement of the biodegradability of model waste water containing recalcitrant or inhibitory chemical compounds by photocatalytic pre-oxidation. Biodegradation. 1997;8(4):237-249.

109. Litter MI. Treatment of Chromium, Mercury, Lead, Uranium, and Arsenic in Water by Heterogeneous Photocatalysis. Advances in Chemical Engineering. 2009;36:37-67.
110. Chen D, Ray AK. Removal of toxic metal ions from wastewater by semiconductor photocatalysis. Chemical Engineering Science. 2001;56(4):1561-1570.

111. Ruvarac-Bugarcic IA, Saponjic ZV, Zec S, et al. Photocatalytic reduction of cadmium on $\mathrm{TiO}_{2}$ nanoparticles modified with amino acids. Chemical Physics Letters. 2005;407(1-3):110-113.

112. Bedja I, Hotchandani S, Kamat PV. Preparation and Photoelectrochemical Characterization of Thin $\mathrm{SnO}_{2}$ Nanocrystalline Semiconductor Films and Their Sensitization with Bis (2,2'-bipyridine)(2,2'bipyridine-4,4'-dicarboxylic acid)ruthenium(II) Complex. J Phys Chem. 1994;98(15):4133-4140.

113. Mitoraj D, Janczyk A, Strus M, et al. Visible light inactivation of bacteria and fungi by modified titanium dioxide. Photochem Photobiol Sci. 2007;6(6):642-648.

114. Karunakaran C, Abiramasundari G, Gomathisankar P, et al. Cu-doped $\mathrm{TiO}_{2}$ nanoparticles for photocatalytic disinfection of bacteria under visible light. J Colloid Interface Sci. 2010;352(1):68-74.

115. Wu B, Huang R, Sahu M, et al. Bacterial responses to $\mathrm{Cu}$-doped $\mathrm{TiO}_{2}$ nanoparticles. Sci Total Environ. 2010;408(7):1755-1758.

116. Karlsson HL, Cronholm P, Gustafsson J, et al. Copper oxide nanoparticles are highly toxic: A comparison between metal oxide nanoparticles and carbon nanotubes. Chem Res Toxicol. 2008;21(9):1726-1732.

117. Yoon KY, Byeon HJ, Park JH, et al. Susceptibility constants of Escherichia coli and Bacillus subtilis to silver and copper nanoparticles. Sci Total Environ. 2007;373(2-3):572-575

118. Newman MD, Stotland M, Ellis JI. The safety of nanosized particles in titanium dioxide-and zinc oxide-based sunscreens. $J$ Am Acad Dermatol. 2009;61(4):685-692.

119. Abstracts for 6th Central European Symposium on Pharmaceutical Technology and Biotechnology. Eur J Pharm Sci. 2005;25(1):S1-S229.

120. Scheinfeld N. Sunscreens: Regulations and Commercial Development, (Cosmetic Science and Technology). 3rd ed. Clinics in Dermatology, London: Taylor and Francis; 2005. p.140-141.

121. Serpone N, Salinaro A, Horikoshi S, et al. Beneficial effects of photoinactive titanium dioxide specimens on plasmid DNA, human cells and yeast cells exposed to UVA/UVB simulated sunlight. Journal of Photochemistry and Photobiology A-Chemistry. 2006;179(1-2):200212

122. Siddiquey IA, Ukaji E, Furusawa T, et al. The effects of organic surface treatment by methacryloxypropyltrimethoxysilane on the photostability of $\mathrm{TiO}_{2}$. Materials Chemistry and Physics. 2007;105(2-3):162-168.

123. Lee WA, Pernodet N, Li B, et al. Multicomponent polymer coating to block photocatalytic activity of $\mathrm{TiO}_{2}$ nanoparticles. Chem Commun (Camb). 2007;45:4815-4817.

124. Park OK, Kang YS. Preparation and characterization of silica-coated $\mathrm{TiO}_{2}$ nanoparticle. Colloids and Surfaces A: Physicochemical and Engineering Aspects. 2005;257-258:261-265.

125. Egerton TA, Everall NJ, Mattinson JA, et al. Interaction of $\mathrm{TiO}_{2}$ nanoparticles with organic UV absorbers. Journal of Photochemistry and Photobiology A: Chemistry. 2008;193(1):10-17.

126. Jacobs JF, Van de Poel I, Osseweijer P. Sunscreens with titanium Dioxide $\left(\mathrm{TiO}_{2}\right)$ nano-particles: a societal experiment. Nanoethics. 2010;4(2):103-113.

127. Gao J-C, Zou J, Tan X-W, et al. Characteristics and properties of surface coated nano- $\mathrm{TiO}_{2}$. Transactions of Nonferrous Metals Society of China. 2006;16(6):1252-1258. 
128. Virkutyte J, Al-Abed SR, Dionysiou DD. Depletion of the protective aluminum hydroxide coating in $\mathrm{TiO}_{2}$-based sunscreens by swimming pool water ingredients. Chemical Engineering Journal. 2012;191:95103.

129. Arora H, Doty C, Yuan Y, et al. Titanium Dioxide Nanocomposites Nanomaterials for the Life sciences. In: Challa S. S. R. Kumar, editor. Weinheim, Germany; 2010. 8:1-51.

130. Yang $\mathrm{H}$, Shi R, Zhang $\mathrm{K}$, et al. Synthesis of $\mathrm{WO}_{3} / \mathrm{TiO}_{2}$ nanocomposites via sol-gel method. Journal of Alloys and Compounds. 2005;398(12):200-202.

131. Zhang Y, Yoneyama Y, Fujimoto K, et al. A new method of bimodal support preparation and its application in Fischer-Tropsch synthesis Topics in Catalysis. 2003;26(1-4):129-137.

132. Sohn JR, Lim SJ. Catalytic Activities of $\mathrm{Al}_{2} \mathrm{O}_{3}$ - promoted $\mathrm{NiSO}_{4} / \mathrm{TiO}$ for acid catalysis. Catalysis Letters. 2006;108(1-2):71-78.

133. Vohra MS, Tanaka K. Photocatalytic degradation of aqueous pollutants using silica-modified $\mathrm{TiO}_{2}$. Water Res. 2003;37(16):3992-3996.

134. Chen X, Wang X, Fu X. Hierarchical macro/mesoporous $\mathrm{TiO}_{2} / \mathrm{SiO}_{2}$ and $\mathrm{TiO}_{2} / \mathrm{ZrO}_{2}$ nanocomposites for environmental photocatalysis. Energy \& Environmental Science. 2009;2(8):872-877.

135. Anderson C, Bard AJ. Improved Photocatalytic Activity and Characterization of Mixed $\mathrm{TiO}_{2} / \mathrm{SiO}_{2}$ and $\mathrm{TiO}_{2} / \mathrm{Al}_{2} \mathrm{O}_{3}$ Materials. $J$ Phys Chem. 1997;101(14):2611-2616.

136. Fu X, Clark LA, Yang Q, et al. Enhanced Photocatalytic Performance of Titania-Based Binary Metal Oxides: $\mathrm{TiO}_{2} / \mathrm{SiO}_{2}$ and $\mathrm{TiO}_{2} / \mathrm{ZrO}_{2}$. Environ Sci Technol. 1996;30(2):647-653.

137. Anderson C, Bard AJ. An Improved Photocatalyst of $\mathrm{TiO}_{2} / \mathrm{SiO}_{2}$ Prepared by a Sol-Gel Synthesis. J Phys Chem. 1995;99(24):9882-9885.

138. Linsebigler AL, Lu G, Yates JT. Photocatalysis on $\mathrm{TiO}_{2}$ Surfaces:principles, mechanisms, and selected results. Chem Rev. 1995;95(3):735-758.

139. Chen X, Mao SS. Titanium dioxide nanomaterials: synthesis, properties, modifications, and applications. Chem Rev. 2007;107(7):2891-2959.

140. Anpo M. Preparation, characterization, and reactivities of highly functional titanium oxide-based photocatalysts able to operate under UV-visible light irradiation: Approaches in realizing high efficiency in the use of visible light. Bulletin of the Chemical Society of Japan. 2004;77(8):1427-1442.

141. Wakefield G, Lipscomb S, Holland E, et al. The effects of manganese doping on UVA absorption and free radical generation of micronised titanium dioxide and its consequences for the photostability of UVA absorbing organic sunscreen components. Photochem Photobiol Sci. 2004;3(7):648-652.

142. Wakefield G, Stott J, Hock J. Sunscreens and cosmetics containing manganese doped titanium oxide nanoparticles. SOFW Journal. 2005;131:46-51.

143. Chen J, Yao MS, Wang XL. Investigation of transition metal ion doping behaviors on $\mathrm{TiO}_{2}$ nanoparticles. Journal of Nanoparticle Research. 2008;10(1):163-171.

144. Yamashita H, Harada M, Misaka J, et al. Degradation of propanol diluted in water under visible light irradiation using metal ion-implanted titanium dioxide photocatalysts. Journal of Photochemistry and Photobiology A: Chemistry. 2002;148(1-3):257-261.

145. Nie XL, Zhuo S, Maeng G, et al. Doping of $\mathrm{TiO}_{2}$ polymorphs for altered optical and photocatalytic properties. International Journal of Photoenergy. 2009:22.

146. Murphy GM. Sunblocks: Mechanisms of action. Photodermatology, Photoimmunology \& Photomedicine. 1999;15(1):34-36.
147. Serpone N, Dondi D, Albini A. Inorganic and organic UV filters:Their role and efficacy in sunscreens and suncare products. Inorganica Chimica Acta. 2007;360(3):794-802.

148. Rampaul A, Parkin IP, Cramer LP. Damaging and protective properties of inorganic components of sunscreens applied to cultured human skin cells. J Photoch Photobio A. 2007;191(2-3):138-148

149. Barker PJ, Branch A. The interaction of modern sunscreen formulations with surface coatings. Progress in Organic Coatings. 2008;62(3):313320 .

150. Tiano L, Armeni T, Venditti E, et al. Modified $\mathrm{TiO}_{2}$ particles differentially affect human skin fibroblasts exposed to UVA light. Free Radic Biol Med. 2010;49(3):408-415.

151. Park B, Martin PA, Harris C, et al. Preliminary in vitro investigation of the potential health effects of Optisol (TM), a nanoparticulate manganese modified titanium dioxide UV-filter used in certain sunscreen products. Nanotoxicology. 2009;3(2):73-90.

152. Lindsay R, Daniels BG, Thornton G. Chapter 5 Geometry of adsorbates on metal oxide surfaces. The Chemical Physics of Solid Surfaces. 2001;9:199-255.

153. Yin JJ, Liu j, Ehrenshaft M, et al. Phototoxicity of nano titanium dioxides in $\mathrm{HaCaT}$ keratinocytes - generation of reactive oxygen species and cell damage. Toxicol Appl Pharmacol. 2012;263(1):81-88.

154. Ehrenberg MS, Friedman AE, Finkelstein JN, et al. The influence of protein adsorption on nanoparticle association with cultured endothelial cells. Biomaterials. 2009;30(4):603-610.

155. Scopelliti PE, Borgonovo A, Indrieri M, et al. The effect of surface nanometre-scale morphology on protein adsorption. PLoS One. 2010;5(7):e11862.

156. Saptarshi SR, Duschl A, Lopata AL. Interaction of nanoparticles with proteins: relation to bio-reactivity of the nanoparticle. $J$ Nanobiotechnology. 2013;11:26.

157. Verma A, Stellacci F. Effect of surface properties on nanoparticle-cell interactions. Small. 2010;6(1):12-21.

158. Worrall JW, Verma A, Yan H, et al. "Cleaning” of nanoparticle inhibitor via proteolysis of adsorbed proteins. Chem Commun. 2006;14(22):23382340 .

159. Sommerfeld J, Richter J, Niepelt R, et al. Protein adsorption on nanoscaled, rippled $\mathrm{TiO}_{2}$ and Si Surfaces. Biointerphases. 2012;7(1-4):55.

160. Horie M, Fujita K, Kato H, et al. Association of the physical and chemical properties and the cytotoxicity of metal oxide nanoparticles: metal ion release, adsorption ability and specific surface area. Metallomics. 2012;4(4):350-360.

161. Horie M, Nishio K, Fujita K, et al. Protein adsorption of ultrafine metal oxide and its influence on cytotoxicity toward cultured cells. Chem Res Toxicol. 2009;22(3):543-553.

162. Sousa SR, Moradas-Ferreira P, Barbosa MA. TiO type influences fibronectin adsorption. J Mater Sci Mater Med. 2005;16(12):1173-1178.

163. Rezwan K, Meier LP, Rezwan M, et al. Bovine serum albumin adsorption onto colloidal $\mathrm{Al}_{2} \mathrm{O}_{3}$ particles: A new model based on zeta potential and UV-Vis measurements. Langmuir. 2004;20(23):10055-10061.

164. Stefano DD, Carnuccio R, Maiuri MC. Nanomaterials toxicity and cell death modalities. J Drug Deliv. 2012;2012:167896.

165. Cedervall T, Lynch I, Lindman S, et al. Understanding the nanoparticleprotein corona using methods to quantify exchange rates and affinities of proteins for nanoparticles. Proc Natl Acad Sci USA. 2007;104(7):20502055.

166. Park EJ, Yi J, Kim Y, et al. Silver nanoparticles induce cytotoxicity by a Trojan-horse type mechanism. Toxicol in Vitro. 2010;24(3):872-878. 
167. Xie X, Gao L. Effect of crystal structure on adsorption behaviors of nanosized $\mathrm{TiO}_{2}$ for heavy-metal cations. Current Applied Physics. 2009;9(3):S185-S188.

168. Ghasemi Z, Seif A, Ahmadi TS, et al. Thermodynamic and kinetic studies for the adsorption of $\mathrm{Hg}(\mathrm{II})$ by nano- $\mathrm{TiO}_{2}$ from aqueous solution. Advanced Powder Technology. 2011;23(2):148-156.

169. Yang JK, Lee SM, Davis AP. Effect of background electrolytes and $\mathrm{pH}$ on the adsorption of $\mathrm{Cu}(\mathrm{II}) / \mathrm{EDTA}$ onto $\mathrm{TiO}_{2}$. J Colloid Interface Sci. 2006;295(1):14-20.

170. Yang YH, Chen H, Pan G. Particle concentration effect in adsorption/ desorption of $\mathrm{Zn}(\mathrm{II})$ on anatase type nano $\mathrm{TiO}_{2}$. J Environ Sci (China). 2007;19(12):1442-1445.

171. Li W, Pan G, Zhang M, et al. EXAFS studies on adsorption irreversibility of $\mathrm{Zn}(\mathrm{II})$ on $\mathrm{TiO}_{2}$ : Temperature dependence. J Colloid Interface Sci. 2008;319(2):385-391.

172. Chithrani BD, Ghazani AA, Chan WC. Determining the size and shape dependence of gold nanoparticle uptake into mammalian cells. Nano Lett. 2006;6(4):662-668.

173. Nativo P, Prior IA, Brust M. Uptake and intracellular fate of surfacemodified gold nanoparticles. Acs Nano. 2008;2(8):1639-1644.

174. See V, Free P, Cesbron Y, et al. Cathepsin L digestion of nanobioconjugates upon endocytosis. ACS Nano. 2009;3(9):2461-2468.

175. Thurn KT, Arora H, Paunesku T, et al. Endocytosis of titanium dioxide nanoparticles in prostate cancer PC-3M cells. Nanomedicine. 2011;7(2):123-130.

176. Johannes L, Lamaze C. Clathrin-dependent or not: Is it still the question? Traffic. 2002;3(7):443-451.

177. Mosesson Y, Mills GB, Yarden Y. Derailed endocytosis: an emerging feature of cancer. Nat Rev Cancer. 2008;8(11):835-850.

178. Geiser M, Rothen-Rutishauser B, Kapp N, et al. Ultrafine particles cross cellular membranes by nonphagocytic mechanisms in lungs and in cultured cells. Environ Health Perspect. 2005;113(11):1555-1560.

179. Singh S, Shi T, Duffin R, et al. Endocytosis, oxidative stress and IL-8 expression in human lung epithelial cells upon treatment with fine and ultrafine $\mathrm{TiO}_{2}$ : Role of the specific surface area and of surface methylation of the particles. Toxicol Appl Pharmacol. 2007;222(2):141-151.

180. Hussain S, Boland S, Baeza-Squiban A, et al. Oxidative stress and proinflammatory effects of carbon black and titanium dioxide nanoparticles: Role of particle surface area and internalized amount. Toxicology. 2009;260(1-3):142-149.

181. Le Roy C, Wrana JL. Clathrin-and non-clathrin-mediated endocytic regulation of cell signalling. Nat Rev Mol Cell Biol. 2005;6(2):112126.

182. Hillaireau H, Couvreur P. Nanocarriers' entry into the cell: relevance to drug delivery. Cell Mol Life Sci. 2009;66(17):2873-2896.

183. Cai R, Kubota Y, Shuin T, et al. Induction of cytotoxicity by photoexcited $\mathrm{TiO}_{2}$ particles. Cancer Res. 1992;52(8):2346-2348.

184. Turkoglu M, Yener S. Design and in vivo evaluation of ultrafine inorganic-oxide-containing-sunscreen formulations. Int J Cosmet Sci. 1997;19(4):193-201.

185. Van der Molen RG, Hurks HM, Out-Luiting C, et al. Efficacy of micronized titanium dioxide-containing compounds in protection against UVB-induced immunosuppression in humans in vivo. $J$ Photochem Photobiol B. 1998;44(2):143-150.

186. Meacock G, Taylor KDA, Knowles MJ, et al. The improved whitening of minced cod flesh using dispersed titanium dioxide. Journal of the Science of Food and Agriculture. 1997;73(2):221-225.
187. Hancock-Chen T, Scaiano JC. Enzyme inactivation by $\mathrm{TiO}$ photosensitization. J Photochem Photobiol B. 2000;57(2-3):193-196.

188. Dunford R, Salinaro A, Cai L, et al. Chemical oxidation and DNA damage catalysed by inorganic sunscreen ingredients. FEBS Lett. 1997;418(1-2):87-90.

189. Lu N, Zhu Z, Zhao X, et al. Nano titanium dioxide photocatalytic protein tyrosine nitration: A potential hazard of $\mathrm{TiO}_{2}$ on skin. Biochem Biophys Res Commun. 2008;370(4):675-680.

190. Ricci A, Chretien MN, Maretti L, et al. $\mathrm{TiO}_{2}$-promoted mineralization of organic sunscreens in water suspension and sodium dodecyl sulfate micelles. Photochem Photobiol Sci. 2003;2(5):487-492.

191. Sayre RM, Dowdy JC. Mineralization of organic sunscreens:interesting, but relevant? Comment and response. Photochem Photobiol Sci. 2003;2(10):1050-1051.

192. Fiserova-Bergerova V, Pierce JT, Droz PO. Dermal absorption potential of industrial chemicals: Criteria for skin notation. Am J Ind Med. 1990;17(5):617-635.

193. Nielsen JB, Grandjean P. Criteria for skin notation in different countries. Am J Ind Med. 2004;45(3):275-280.

194. Sartorelli P, Ahlers HW, Alanko K, et al. How to improve skin notation. Position paper from a workshop. Regul Toxicol Pharmacol. 2007;49(3):301-307.

195. Smijs T, Pavel S. Titanium dioxide and zinc oxide nanoparticles in sunscreens: focus on their safety and effectiveness. Nanotechnol Sci Appl. 2011;4:95-112.

196. Nohynek GJ, Antignac E, Re T, et al. Safety assessment of personal care products/cosmetics and their ingredients. Toxicol Appl Pharmacol. 2010;243(2):239-259.

197. Nohynek GJ, Dufour EK. Nano-sized cosmetic formulations or solid nanoparticles in sunscreens: A risk to human health? Arch Toxicol. 2012;86(7):1063-1075.

198. Baroli B. Penetration of nanoparticles and nanomaterials in the skin:Fiction or reality? J Pharm Sci. 2010;99(1):21-50.

199. Chen X, Schluesener HJ. Nanosilver: A nanoproduct in medical application. Toxicol Lett. 2008;176(1):1-12.

200. Nohynek GJ, Lademann J, Ribaud C, et al. Grey Goo on the Skin? Nanotechnology, Cosmetic and Sunscreen Safety. Crit Rev Toxicol. 2007;37(3):251-277.

201. Tan MH, Commens CA, Burnett L, et al. A pilot study on the percutaneous absorption of microfine titanium dioxide from sunscreens. Australas J Dermatol. 1996;37(4):185-187.

202. Lademann J, Weigmann HJ, Rickmeyer C, et al. Penetration of Titanium Dioxide Microparticles in a Sunscreen Formulation into the Horny Layer and the Follicular Orifice. Skin Pharmacol Appl Skin Physiol. 1999;12(5):247-256.

203. Gamer AO, Leibold E, Van Ravenzwaay B. The in vitro absorption of microfine zinc oxide and titanium dioxide through porcine skin. Toxicol in Vitro. 2006;20(3):301-307.

204. Schulz J, Hohenberg H, Pflucker F, et al. Distribution of sunscreens on skin. Adv Drug Deliv Rev. 2002;54(Suppl 1):S157-S163.

205. Mavon A, Miquel C, Lejeune O, et al. In vitro percutaneous absorption and in vivo stratum corneum distribution of an organic and a mineral sunscreen. Skin Pharmacol Physiol. 2007;20(1):10-20.

206. Lekki J, Stachura Z, Da bros W, et al. On the follicular pathway of percutaneous uptake of nanoparticles:Ion microscopy and autoradiography studies. Nuclear Instruments and Methods in Physics Research Section B: Beam Interactions with Materials and Atoms. 2007;260(1):174-177. 
207. Pinheiro T, Pallon J, Alves LC, et al. The influence of corneocyte structure on the interpretation of permeation profiles of nanoparticles across skin. Nuclear Instruments and Methods in Physics Research Section B: Beam Interactions with Materials and Atoms. 2007;260(1):119-123.

208. Kiss B, Biro T, Czifra G, et al. Investigation of micronized titanium dioxide penetration in human skin xenografts and its effect on cellular functions of human skin-derived cells. Exp Dermatol. 2008;17(8):659667.

209. Filipe P, Silva JN, Silva R, et al. Stratum corneum is an effective barrier to $\mathrm{TiO}_{2}$ and $\mathrm{ZnO}$ nanoparticle percutaneous absorption. Skin Pharmacol Physiol. 2009;22(5):266-275.

210. Gontier E, Ynsa MD, Biro T, et al. Is there penetration of titania nanoparticles in sunscreens through skin? A comparative electron and ion microscopy study. Nanotoxicology. 2008;2(4):218-231.

211. Wokovich A, Tyner K, Doub W, et al. Particle size determination of sunscreens formulated with various forms of titanium dioxide. Drug Dev Ind Pharm. 2009;35(10):1180-1189.
212. Monteiro-Riviere NA, Wiench K, Landsiedel R, et al. Safety Evaluation of Sunscreen Formulations Containing Titanium Dioxide and Zinc Oxide Nanoparticles in UVB Sunburned Skin: An In Vitro and In Vivo Study. Toxicol Sci. 2011;123(1):264-280.

213. Cevc G. Lipid vesicles and other colloids as drug carriers on the skin. Adv Drug Deliv Rev. 2004;56(5):675-711.

214. Wissing SA, Muller RH. Solid lipid nanoparticles as carrier for sunscreens: in vitro release and in vivo skin penetration. $J$ Control Release. 2002;81(3):225-233.

215. Honeywell-Nguyen PL, Groenink HWW, Bouwstra JA. Elastic vesicles as a tool for dermal and transdermal delivery. J Liposome Res. 2006;16(3):273-280.

216. Scientific Committee on Cosmetic Products and Non-Food Products Intended for Consumers (SCCNFP). Opinion concerning titanium dioxide. European Commision. 2000. 